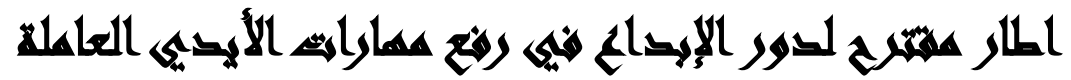

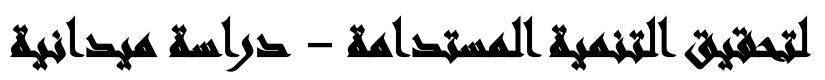

رانده جمال عبدالمنعم(')- أسامة محمود فريد (ץ)-- هدى ابراهيم هلال(r)

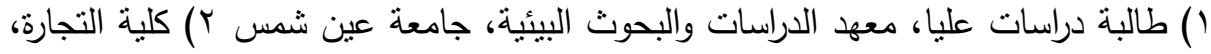

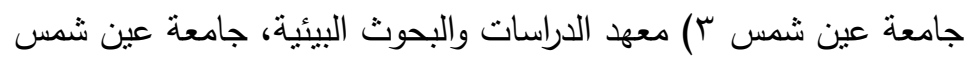

\section{المستخلص}

تهدف الدراسة الى التعرف على واقع الإبداع الاداري لرفع مهارات الايدي العاملة ومن

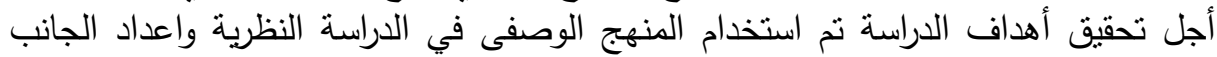

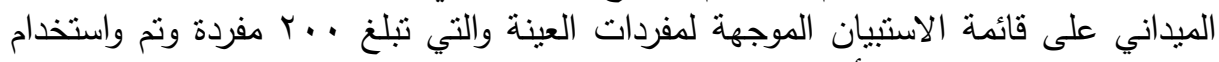

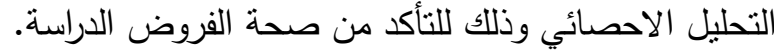
وقد توصلت الاراسة المى النتائج الآتبة:

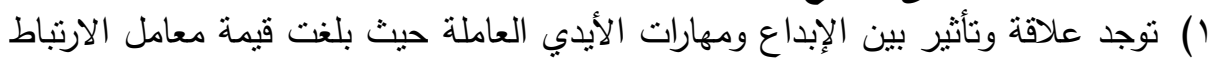

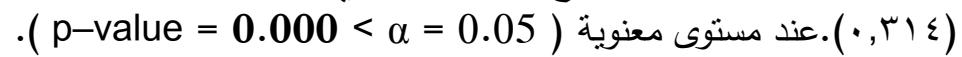

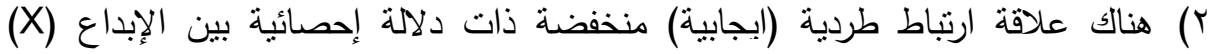

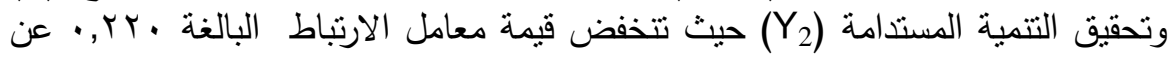

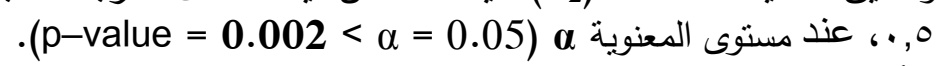
ومن أهم التوصيات التي يقدمها الباحثون ما ليالي: 1) تركيز الحكومة ومنظمات العمل المدني على تتمية المسئولية البيئية لتحقيق اكبر استفادة التئية

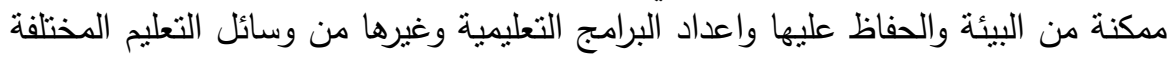
لرفع مستوى المسئولية البيئية لإى الافراد. r) تدريب وتتمية الموارد البشرية بندا استثمارياً في الموازنة التخطيطية في المنظمة الحديثة .

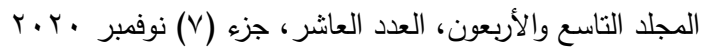

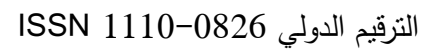


مجلة العلوم البيئية

معهد الدراسات والبحوث البيئية - جامعة عين شمس لهنه

رانده جمال عبدالمنعم وآخرون

\section{مهتيمة الصراسة}

تواجه المنظمات على اختلاف أنو اعها وأحجامها ومهامها - تحدياً مشتركًا يتمنل في

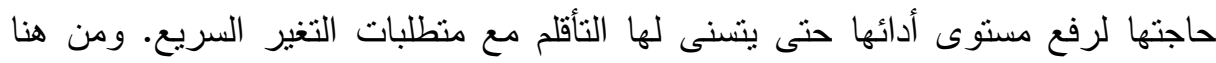

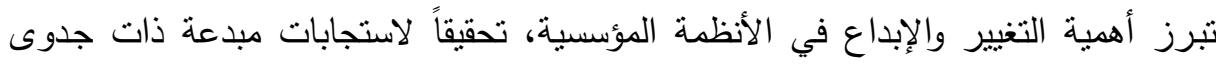
وفعالية للتحديات التي يبرزها التغيير في مجالات التتمية والتطور الحضاري. (السرور،

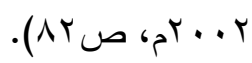

فالفرد المبدع يعتبر ثروة تفوق الثروة المادية، بل إن الاستثمار في نطوير العنصر

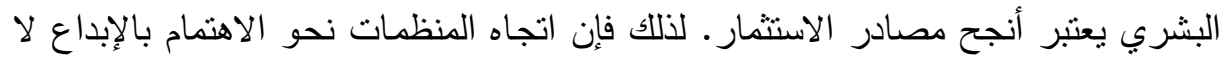
ينبغي أن يقتصر على إدخال الأدوات والتقنيات المنطورة، بل لابد أن يشمل إحداث

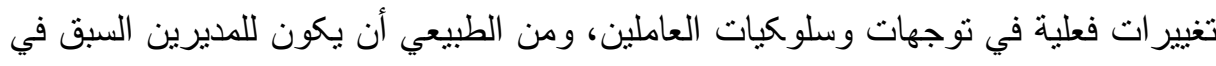
تمثيل السلوكيات و التوجهات المطلوبة، كونهم أكثر المتغيرات أهمية في تسيبير شئونئن المنظمات. هذا فضد لال عن أن تطوير الإدارة يستتد بالدرجة الأولى إلى مجموعة القيم

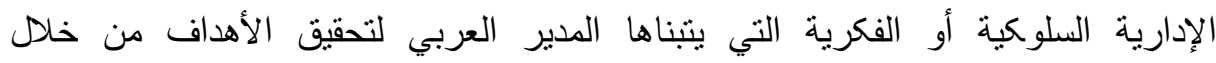
الآخرين، أكثر من استتادها لاستخدام أداة علمية أو إدخال تكنولوجيا جديدة. (حمدان،

كما وأن الإبداع أصبح الآن بمثابة الأمل الأكبر للجنس البشري لحل الكثير من

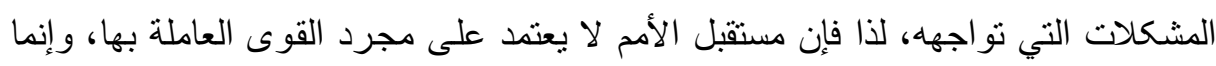

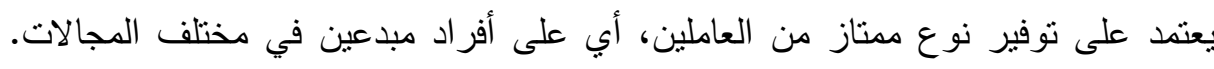

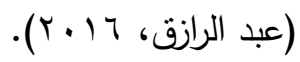

كما ينبخي تقدير أهمية دور الإبداع الإداري من خلال جهود ملحوظة لتوفير مناخ ملائم يمكن للعاملين في المنظمات على اختلاف مستوياتهم من إظهار ما لديهم من قدر الإبدات الإدي

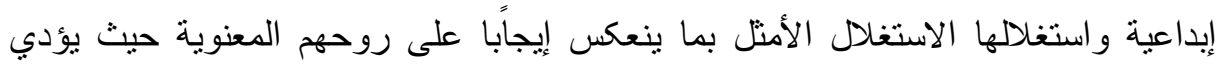

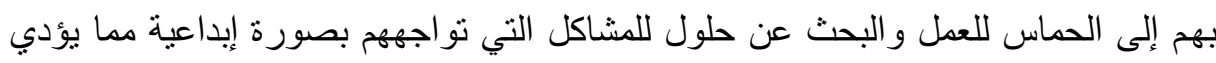
392

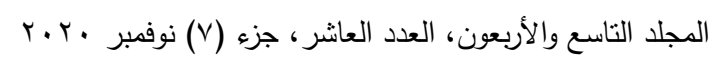

التزقيم الدولي 


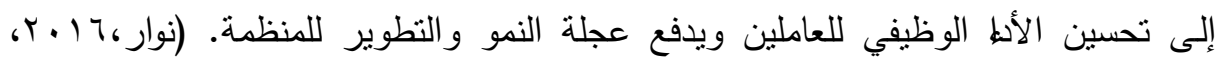
ص ص (

فالمنظمات العامة لم تأخذ بجدية أهمية خلق المناخ المساند للمبتكرين، وبالتالي ينبغي على هذه المنظمات إجري القياسات المختلفة التي من شأنها تحديد القدرات الحالية الابتكارية

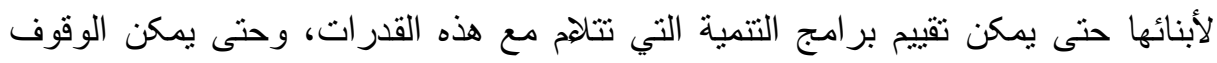
على مدى تأثثر المتغيرات المختلفة المحيطة بالعاملين والتي تؤثر في مستوى القدرات لهات

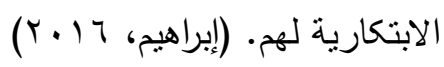

\section{And ILan}

قدمت العديد من الدراسات حول دور الإبداع في رفع مهارات الأيدي العاملة لتحقيق

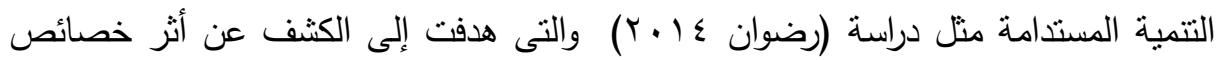
منظمات التعلم فى السلوك الإبداعى لدى العاملين فى البنوك التجارية المصرية وقد اختبرت الدراسة عدة أبعاد لرفع مهارات الأيدى العاملة لتحقيق التتمية ن وكذلك دراسة (الرواشدة

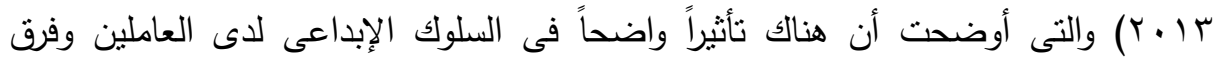
العمل ثم التعلم المستمر ثم الحوار والاستفسار ثم التمكين الإدارى وأخيراً القيادة الاستراتيجية

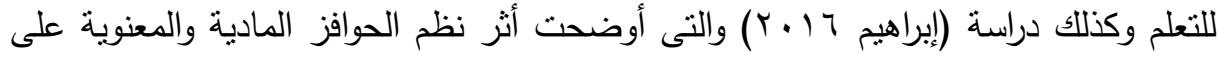

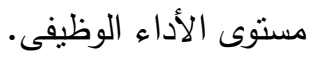

وبالرغم من المنظمات على اختلاف أنواعها وأحجامها ومهامها تواجه تحدياً مشتركاً يتمثل في حاجتها لرفع مستوى أدائها حتى ينسنى لها التأقلم مع منطلبات التغير السريع. ومن هنا ظهرت مشكلة البحث الحالية فى إبراز أهمية التلازم بين إدارة التغيير والإبداع في النظام المؤسسي، تحقيقاً لاستجابات مبدعة ذات جدوى وفعالية للتحديات التي يبرزها التغيير في مجالات التتمية و التطور الحضاري. وذلك بهدف تقصى ودراسة وتحليل

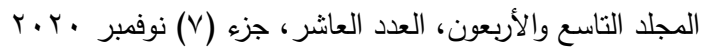

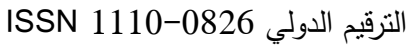


للتعرف على واقع الإبداع الاداري لرفع مهارات الايدي العاملة ومعرفة الأسباب الحقيقية لواقع

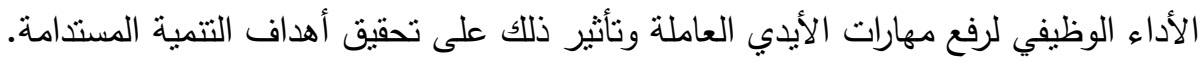

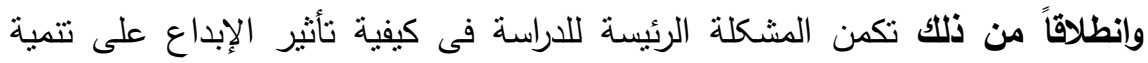

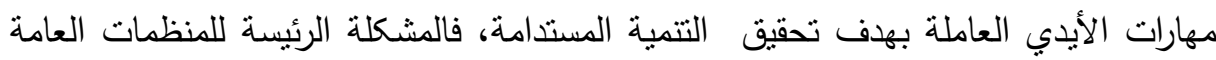
أنها لم تأخذ بجدية أهمية خلق المناخ المساند للمبتكرين، وبالتالي ينبغي على هذه المنظمات إجراء القياسات المختلفة التي من شأنها تحديد القدرات الحالية الابتكارية حتى يمكن تقييم

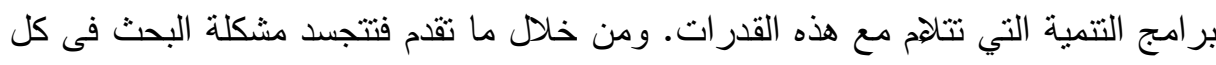
من الآتى: برات الت ا-قلة وندرة المهارات الإدارية والفنية للعاملين بوظائف داخل الجامعة مما يؤثر على الإثل الإبداع وتحقيق التنمية المستدمة. r-قلة المهارات لها تأثثر إيجابى على فاعلية تطبيق متطلبات التتمية المستدامة واختلاف ذلك حسب خصائص كل موظف. r- قلة الجهود الجامعية التى تؤمن بضرورة تتمية المهارات العاملين مما يعوق عملية تتمية

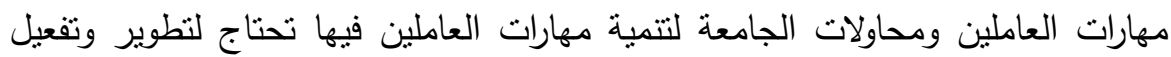

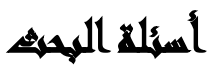

$$
\begin{aligned}
& \text { هنالك العديد من التساؤلات التي تسعى هذه الدراسة للإجابة عنها وهي: }
\end{aligned}
$$

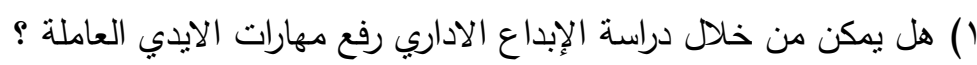

$$
\begin{aligned}
& \text { r) ما مستوى الإبداع الإداري لاى المديرين وعلاقته برفع مهارات الأيدى العاملة. } \\
& \text { ץ) ما امكانية تحديد المعلومات الناقصة واكمالها وتفادى تلأك المشكلات. } \\
& \text { ع) ما هي العلاقة بين الابداع الاداري وتحقيق أهداف التتمية المستدامة ؟ } \\
& \text { 0) ما امكانية رفع مهارات الأيدى العاملة والتغلب على تلك المشكلات. }
\end{aligned}
$$

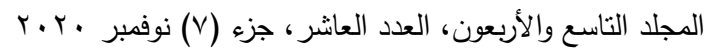

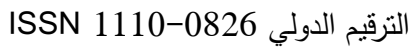




\section{مجلة العلوم البيئية \\ معهد الدراسات والبحوث البيئية - جامعة عين شمس لئن

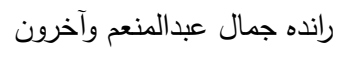

7) ما هو دور دراسة واقع الأداء الوظيفي فى رفع مهارات الأيدي العاملة وهل هناك علاقة وطيدة بينهما؟

\section{أهمية الهبهم}

يمكن تحديد الأهمية العلمية والتطبيقية على النحو النالي:

- من الناحية العلمية: " دراسة التأثير الحيوي للإبداع الإداري في تحقيق أهداف المنظمات العامة " ، هذا الموضوع مازال بحاجة الى مزيد من الدراسة والتحليل في المجال

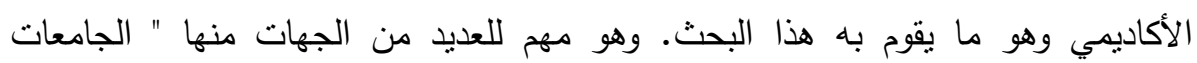

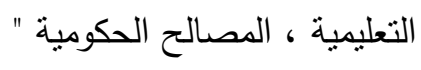

- من الناحية التطبيقية: يستمد البحث أهميته التطبيقية حيث يساهم في التعرف على التى التأثنر الحيوي للإبداع الإداري في تحقيق أهداف المنظمات العامة وتحقيق اهداف التتمية المستدامة.

\section{أهفاهي المهمث}

الهُف الأساسي للبحث هو " دراسة التعرف على واقع الإبداع الاداري وذلك بهذف

رفع مهارات الايدي العاملة " وينشأ عن هذا الهدف الرئيسى الأهداف الفرعية التالية:

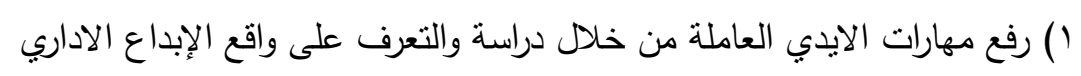

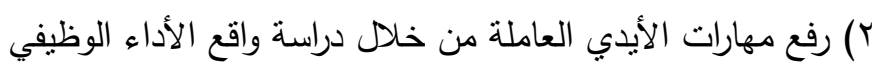

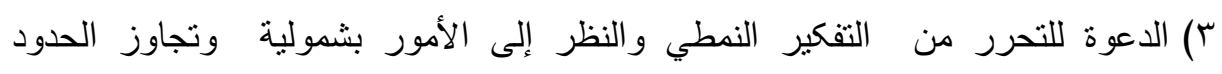
الجامدة للتوصل إلى حلول إبداعية خلاقة.

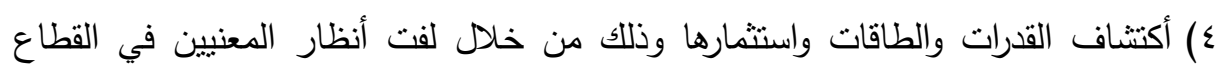

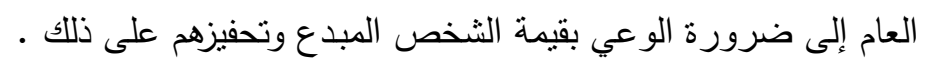

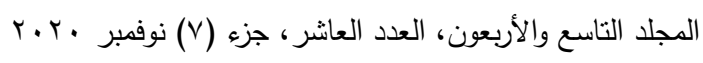

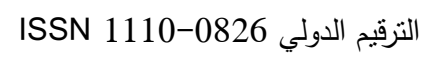


مجلة العلوم البيئية

معهد الدراسات والبحوث البيئية - جامعة عين شمس له

رانده جمال عبدالمنعم وآخرون

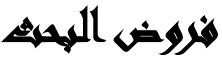

تم صياغة الفروض التالية كأسباب محتملة للمشكلة محل الدراسة كالتالي: الفرض الرئيسي الأول : نوجد علاقة ذات دلالة معنوية بين الإبداع و مهارات الايدي العاملة.

الفرض الرئيسي الثاني : وجود علاقة إرتباط طردية (إيجابية) ذات دلالة احصائية بين الإبداع ومهارات الأيدى العاملة.

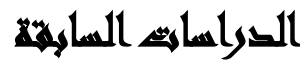

أولاً: الاراسات السابقة العربيةة:

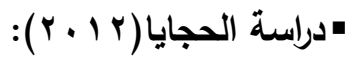

هدفت الدراسة: إلى معرفة ضغوط العلم وعلاقتها بالسلوك الإبداعى لدى مديرى المدارس الثانوي الحكومية فى إقليم جنوب الأردن من وجهة نظرهم.

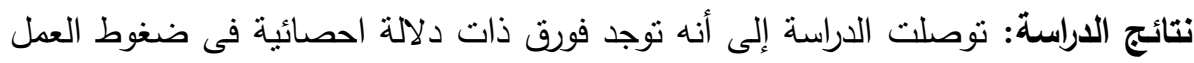

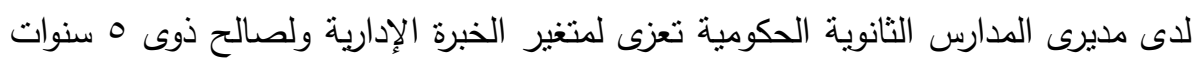

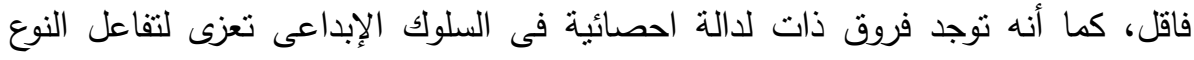

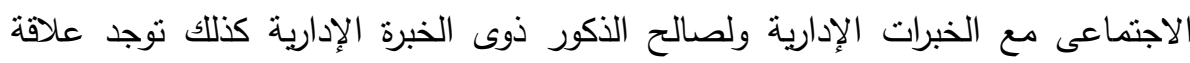

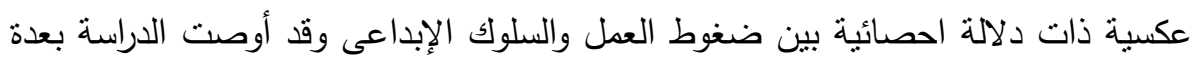
توصيات مها كضرورة اهتمامات وزارة التربية والتعليم بالمصادر التى لها دور فى خلق دلقين ضغوط العمل لدى المديرين ومحاولة مساعدتهم فى التخلص منها، باعتبارها ذات نأنثير سلبى فى السلوك الإبداعى.

$$
\begin{array}{r}
\text { المجلد التاسع والأربعون، العدد العاشر ، جزء (V) نوفمبر ·.r. الترقيم الدولي 0826- 1110 } \\
\text { ISSN }
\end{array}
$$




$$
\begin{aligned}
& \text { مجلة العلوم البيئية } \\
& \text { معهد الدراسات والبحوث البيئية - جامعة عين شمس لئس } \\
& \text { رانده جمال عبدالمنعم وآخرون }
\end{aligned}
$$

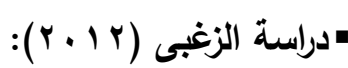

هدفت الدارسة: إلى التعرف على عناصر الدناخ التنظيمى السائد فى شركة أورانج الأردنية

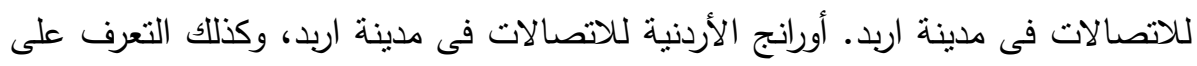

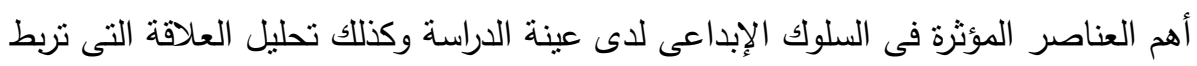

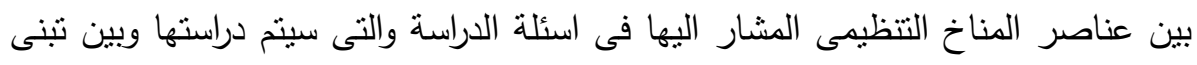
السلوك الإبداعى. وكذلك التعرف على العلاقة بين الخصائص الوظيفية والثخصية للعاملين (الجنس، العمر، الحالة الاجتماعية، الدستوى التعليمى، الخبرة) وتبنى السلوك الإبداعى العيل للعاملين.

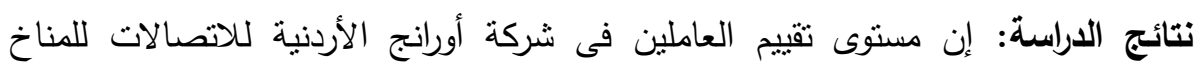
التنظيمى السائد كان إيجابياً وذا مستوى منوسط. وعدم وجود تأثير دال احصائيا لإنيا للهيكل

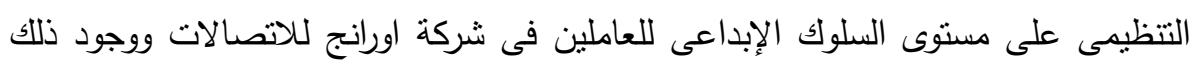

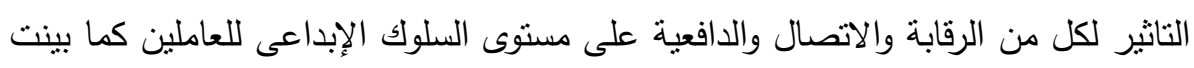

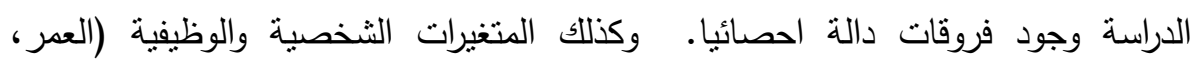

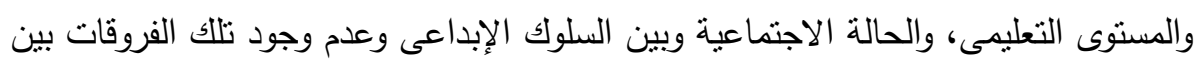
المتغيرات الثخصية والوظيفية (الجنس، الخبرة، وبين السلوك الإبداعى للعاملين).

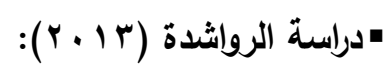

هدفت الدراسة إلى: معرفة تصورات المبحوثين حول الغارة بالتجوال لاى شركة البوتاس الباس

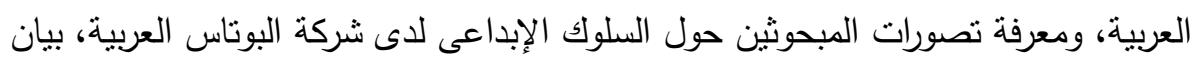

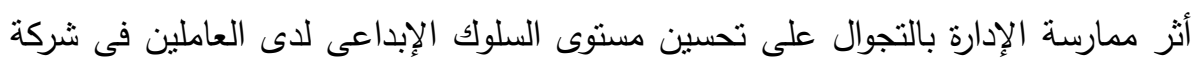

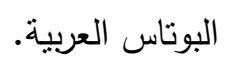

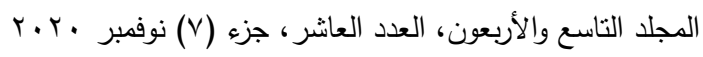

$$
\begin{aligned}
& \text { التزقيم الدولي }
\end{aligned}
$$


نتائج الدراسة: أظهرت نتائج الدراسة أن مسنوى كل من ممارسة الإدارة بالتجوال والسلوك

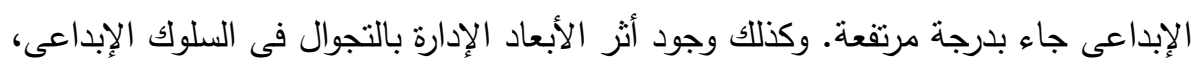

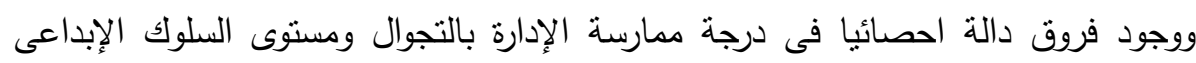

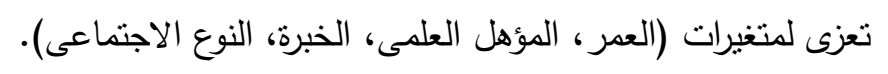

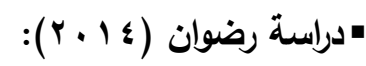

هدفت الدراسة: إلى الكثف عن أثز خصائص منظمات التعلم فى السلوك الإبداعى لدى العاملين فى البنوك التجارية المصرية وقد اختبرت الدراسة عدة أبعاد لمنظمات التعلم (التعلم

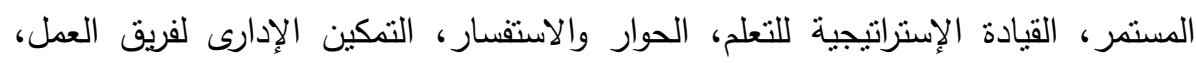
وذلك على السلوك الإبداعى. نتائج الدراسة: استتتجت الدراسة إلى أن هناك اثر ذى دلالة احصائية لخصائص منظمات

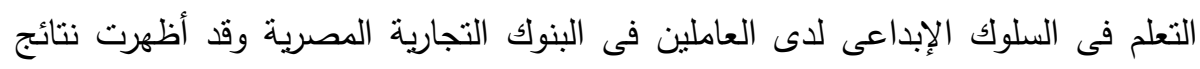

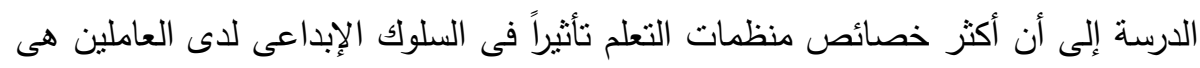
فرق العمل ثم التعلم المستمر ثم الحوار والاستفسار ثم التمكين الإدارى وأخيراً القيادة الاستراتيجية للتعلم.

ثانياً : الاراسات السابقة الأجنبية:

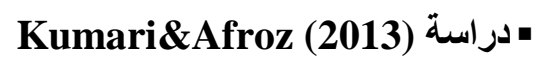
هدفت الدراسة إلى ما يلى (2013 - - دراسة العدالة التتظيمية، وعلاقتها بالإلتزام التتظيمى والسلوك الإبداعى لدى العاملين فى الطاقة الحرارية. - - دراسة دور العدالة التتظيمية فى الإلتزام التتظيمى لدى العاملين فى الطاقة الحرارية. - - دراسة أثر العدالة التنظيمية فى السلوك الإبداعى لاى العاملين فى الطاقة الحرارية.

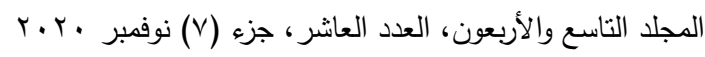

$$
\begin{aligned}
& \text { التزقيم الدولي 0826-0 التون، }
\end{aligned}
$$


نتائج الاراسـة:

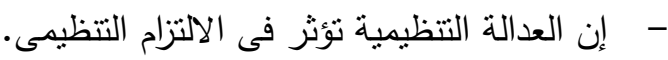

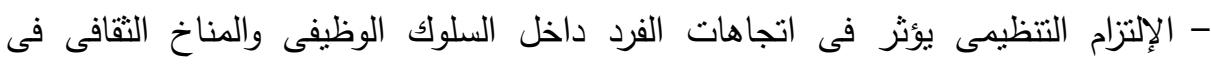

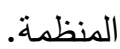
- العدالة التتظيمية تؤثر بشكل فعال فى السلوك الإبداعى للموظف.

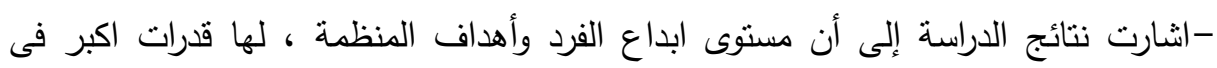
ترجمة العدالة تجاه المنظمة فى الأداء الإبداعى.

• دراسة (2013) Nejadirani \& Others هافت الاراسة إلى ما يلى: نقييم حالة العدالة التتظيمية وابعادها وعلاقتها بإبداع الموظف فى مقاطعة Bookan نتائجج الاراسة: - توجد علاقة ذات دلالة احصائية بين العدالة التوزيعية وبين ابداع الموظفين. - توجد علاقة ذات دلالة احصائية بين العدالة الإجرائية وبين ابداع الموظفين. - توجد علاقة ذات دلالة احصائية بين العدالة التفاعلية وبين ابداع الموظفين.

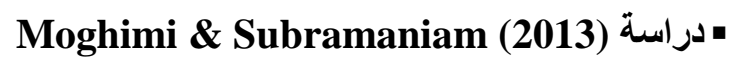
هدفت الدراسة إلى ما يلى: تحديد أثز إبداع الموظف وابتكاره الذى يعد ميزة تتافسية للنجاح وبقاء المنظمات ودراسة الأبعاد المختلفة التى نتكل العناخ التتظيمى وبحثت في العلاقة بينها وبين سلوك الموظفين الإبداعى.

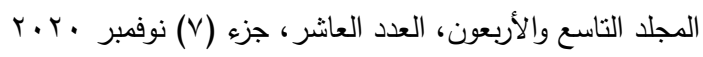

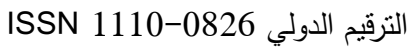




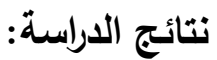

- إن أبعاد المناخ التتظيمى يمكن أن يكون افضل مؤشر لسلوك الموظفين الإبداعى.

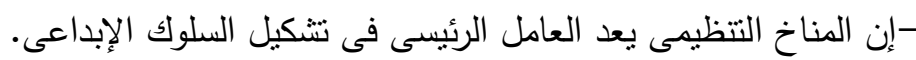

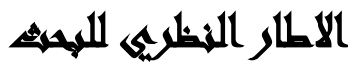

يشها العصر الحالي العديد من التطورات المتسارعة والتغييرات المتلاحقة نتيجة الانفجار المعرفي وثورة المعلومات والاتصالات ولعل استمرار التقدم العلمي والتطور

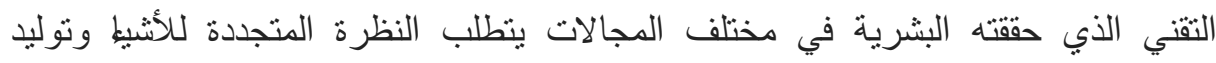

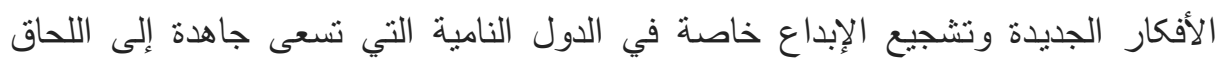

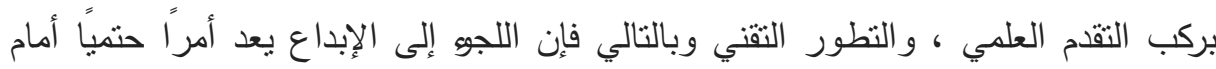

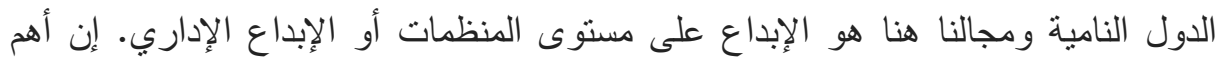

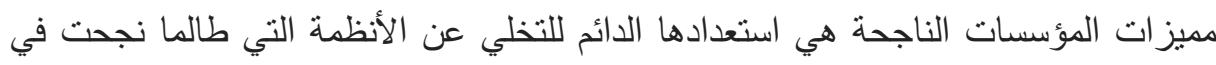
أديا مهامها ولكن هذا لا يعنى بالطبع أن كل جديد أفضل من القديم ولكن الأشياء الجيدة

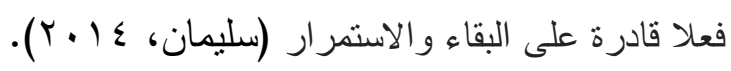

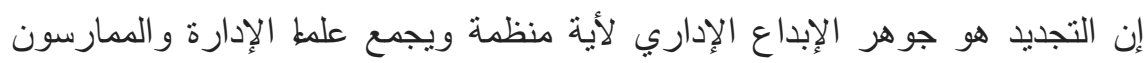

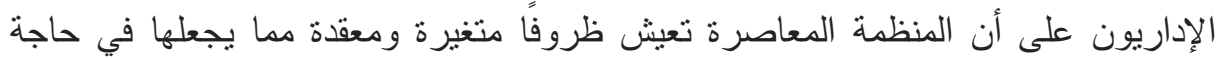
ملحة إلى الإبداع الإداري ،فهو يسهم في نحسين قدرات العات العالملين على توليد الأفكار ومواكبة التطورات النقنية الحديثة وحل المشكلات والمشارعة في انخاذ القرارات

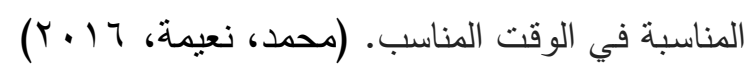

ومن هنا نرى أن الإبداع الإداري منظومة متكاملة تتنترك فيها المنظمة الإدارية

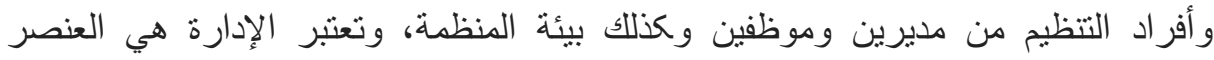
الفاعل في أنط المنظمة

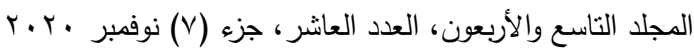

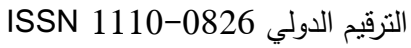


مفاهيم الإبداع ومكوناته

الكثير يجمع على أنه قدرة عقلية تظهر على مستوى الفرد أو الجماعة أو المنظمة وهو عملية ذات مراحلم تعددة ينتج عنها فكر أو عمل جديد يتميز بأكبر قدر من الطلاقة والمرونة والأصالة والحساسية للمشكلات والاحتفاظ بالإتجاه ومواصلته كما يتميز بالقدرة على التركيز لفترات طويلة فى مجال الاهتمام، والقدرة على تكوين ترابطات واكتثافات وعلاقات جديدة وهذه القرة يمكن تتميتها وتطويرها حسب قدرات وإمكانات الأفراد والجماعات والمنظمات (سلامة،

واختلف العلماء في تعريفهم للإبداع فبعضهم يقصد بالإبداع القدرة (Ability ) على آلى أخد خلق شيء جديد أو مبتكر ، بينما يقصد آخرون أنه العملية (Process ) أو العطليات

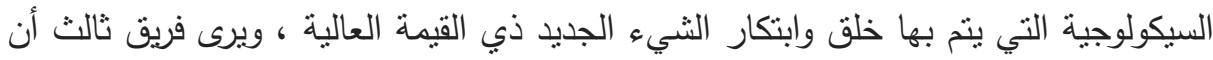

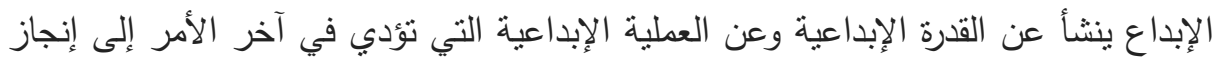

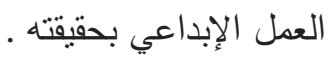

لكي نتعرف على الإبداع بشكل أدق لابد من التعرف إلى مكوناته أو القدرات التي يتكون

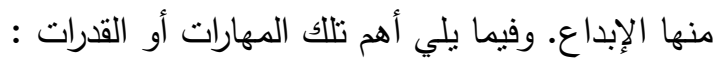

1- الطلاقة: تعني القدرة على خلق أفكار أو بدائل أو جديدة وبسرعة ومن أنوات أنواع الطلاقة :

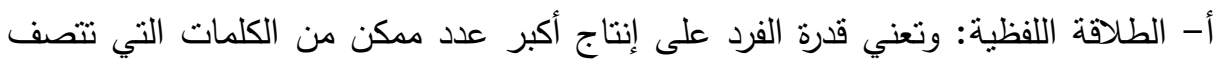

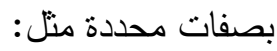

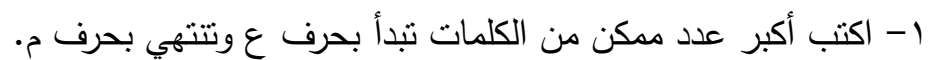

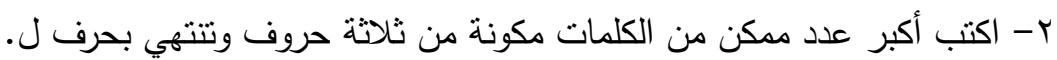
ب- الطلاقة الفكرية: وتعني قدرة الفرد على إعطاء أكبر عدد ممكن من المعاني أو الحلول لمشكلة أو العناوين لفقرة أو الاستعمالات المختلفة لشيء

$$
\begin{aligned}
& \text { r.r. الهجلد الثاسع والأربعون، العدد العانشر ، جزء (V) نوفمبر } \\
& \text { التزقيم الدولي 0826- نالعين }
\end{aligned}
$$


ويرى دونالا ماكينون ( Mackinnon ) الباحث المشهور في الإبداع أنه لا يمكن تحديد

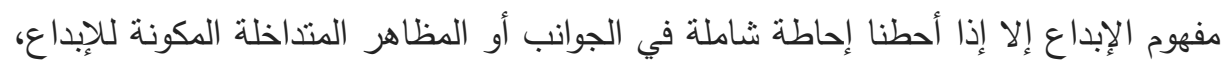

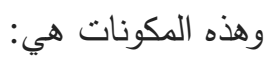

1-الإنتاج الإبداعي : ( Creative Products ) هو أحد جوانب تفاعل الإنسان مع البيئة ويقاس الإبداع في أحد جوانبه بكمية الإنتاج وصوره ، فالإنتاج الإبداعي محك أو مقياس للإبداع. و فرق دونالد تبلر ( D.W. Taylor ) بين التفكير الإبداعي وحل المشكلات

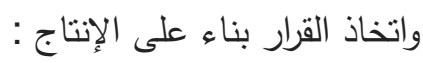
r- العملية الإبداعية : ( Creative Process ) عملية معرفية ذهنية ، حيث يكون الفرد في هذه العملية نشطا منظما للخبرات لكي يستجيب للموقف الجديد . أهمية الإبداع الإدارى: تبدو أهمية الإبداع الإدارى فى الآتى:

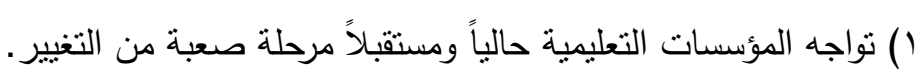

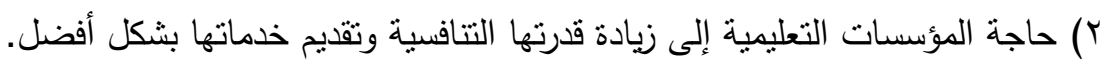

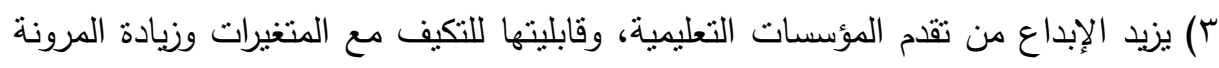
في عملياتها الإدارية والفنية المستمرة. ع) يساعد الإبداع على اكتشاف ودعم قدرات الأفراد الذاتية وتوجيهـا نحو نطوير المدرسة. 0) يساعد الإبداع في تحقيق الذات والثعور بالإنجاز لجميع العاملين في المدرسة.

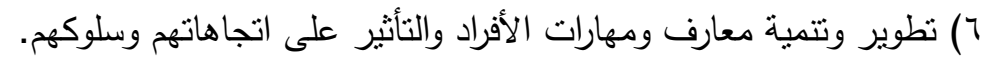

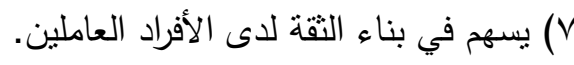

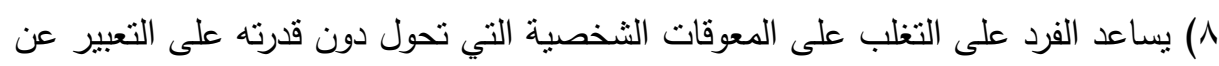
إمكاناته الإبداعية. 9) يوضح للأفراد مسارات التطوير والتجديد في منظماتهم. • (1) يدفع الأفراد إلى الدخول في منافسات التحدي والتميز مع الآخرين. 
(1) يساعد الأفراد في إعادة تحديد أهدافهم وتصوراتهم عن العمل، وبالتالي قدرتهم على الظهور بصور إبداعية متجددة ومستمرة يساعد الأفراد في إعادة تحديد أهدافهم وتصوراتهم عن العمل، وبالتالي قدرتهم على الظهور بصور إبداعية متجددة ومستمرة.

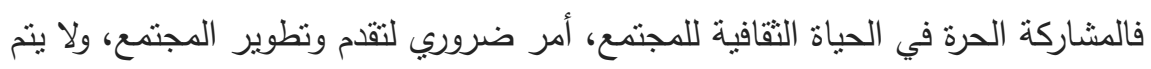
ذللك إلا في جو إيجابي يسوده العدل وتوافر الضمانات الرئيسة لحماية حقوقه، التي تعني: الحق في اكتساب مقومات الحياة الثقافة العصرية، كحق التعرف على الأشكال العلمية الحديثة

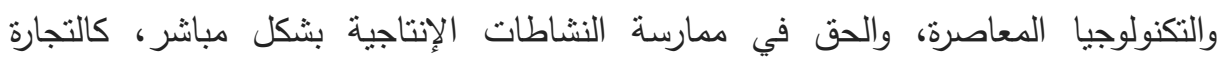
وملحقاتها، وكنللك تثجيع وتوفير إمكانات الإبداع في المجالاتومن النقاط المهمة في معالجة

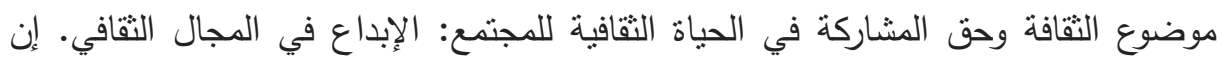
الإبداع مطلب اجتماعي في جميع حقول وميادين الحياة، ولكن هذا المطلب يجب أنب فئن يكون

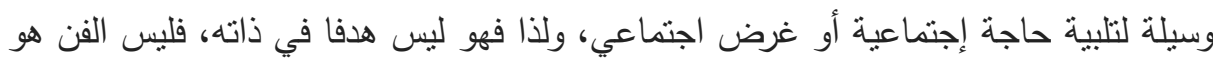

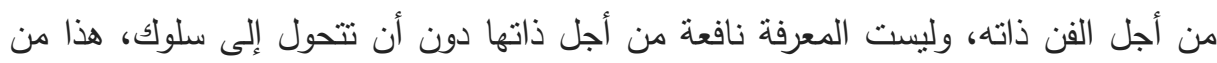
جهة. ومن جهة أخرى، أن الإبداع والقلق الإبداعي لدى الآخر يرتبط في قنم من من معانيه

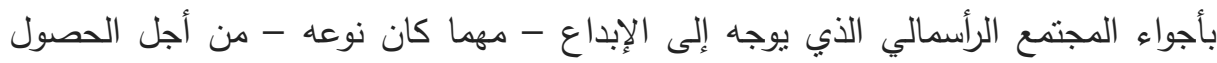

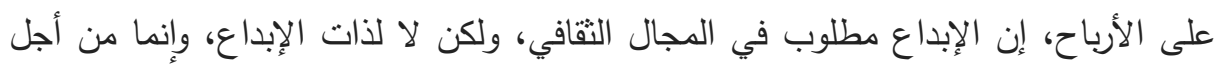

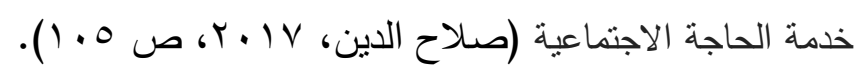

ولذا لابد للإبداع من أن يقوم على بعد النقويم والتهذيب، إذ ما قيمة الإبداع إذا كان

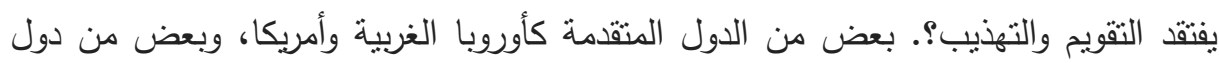
العالم الثالث اهتم بهذا الأمر وقام بتشجيع مواطنيه على الإبداع في الإنتاج الفني والأدبي

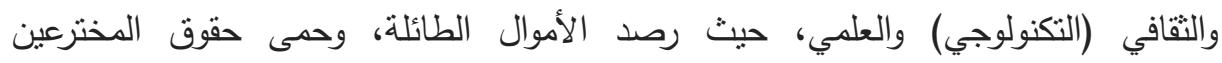
والمبدعين المادية والمعنوية، وأنثأ أجهزة ومؤسسات تهتم بهذا المجال وتثوم بمساعدة أبناء المجتمع عبر توفير إمكانات الإبداع ودعوتهم إلى المشاركة في معالجة المعضلات التهات التي

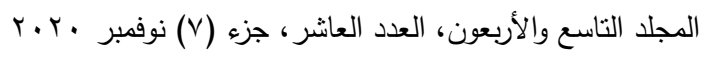

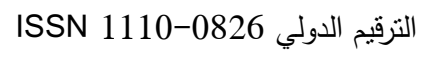


تواجه البلاد. مما عزز دور المثققين والمتعلمين وأصحاب الاختراعات النقنية في المجتمع، رأهن

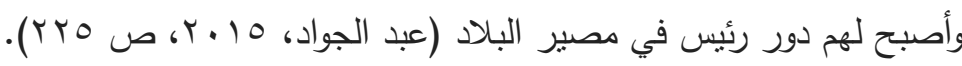

أما في دول العالم الثالث فحصل العكس حيث نم حرمان كثيرين من المشاركة الفعلية في الحركة النطويرية والإبداعية، وانتهكت حقوق المبدعين والمنتجين في مختلف المجالات النقافية والاجتماعية، لذلك حدث نزيف الأدمغة في تلك الدول، وأدّى إلى هجرة كثير من فئن

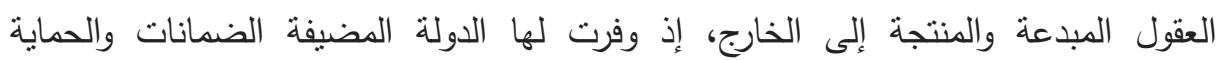

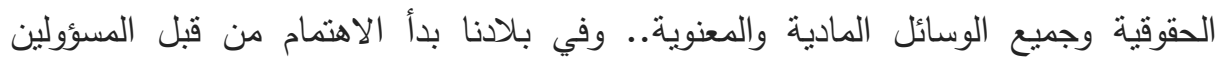

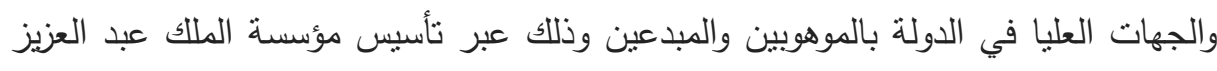
ورجاله لرعاية الموهوبين، وهي مؤسسة وطنية حضارية تحظى برئاسة خادم الحرمين بادين

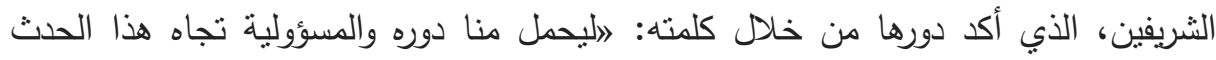

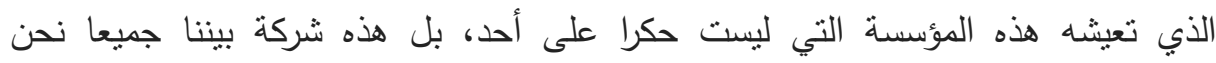

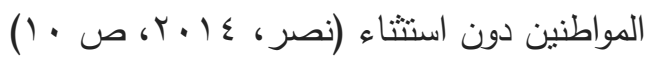

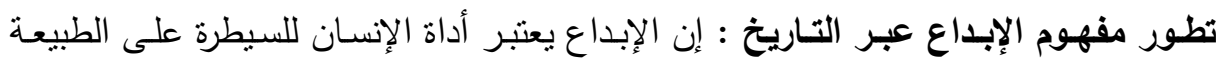

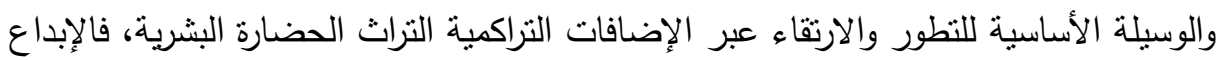

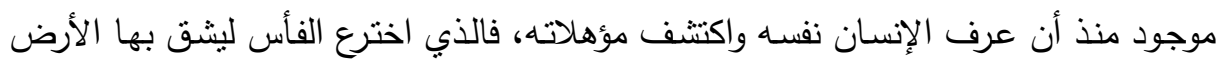
هو إنسان مبدع بالتأكيد بمفهوم عصره. ولقد مر مفهوم الابداع بثلاث مراحل عبر التـاريخ (سليمان، ه 1 ـ ب)، وهذه المراحل المرحلة الأولي: (الخلط بين المقاهيم) المرحلة الثانية: (العوامل المؤتمرة على الإبداع: بيئية - وراثية

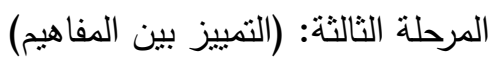

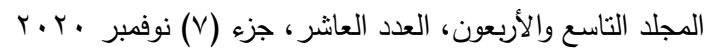

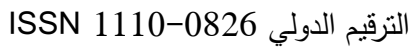


وقد أصبحت ظاهرة تطور مفهوم الإبداع هى الشغل الثاغل لكثير من العلماء في شتي

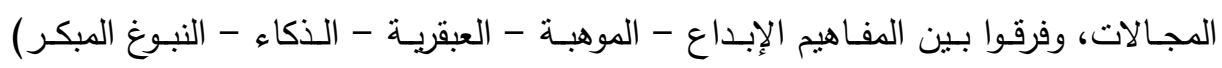

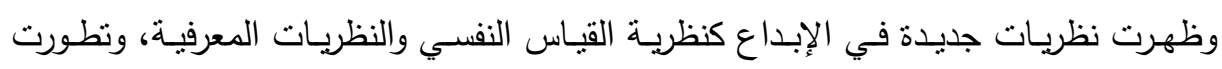

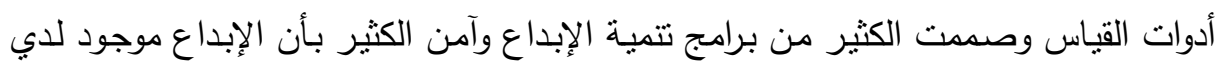

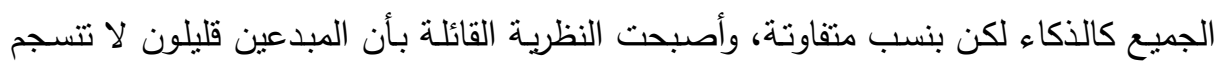

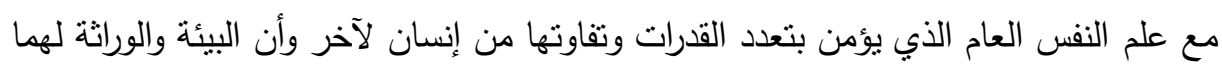

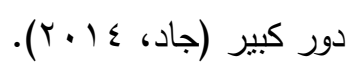
دور الإبداع الإدارى فى المجتمع: دواديز إن مختلف العوامل الأساسية المكونة للقدرة على التفكير الابتكاري التي نتاولناها في هذا

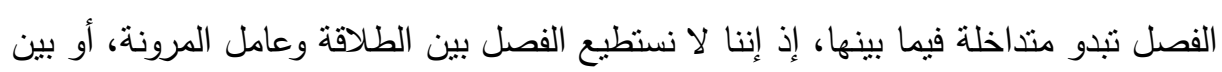

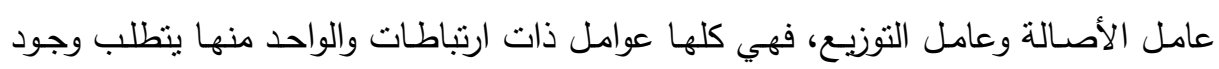
الأخر • والمشكلة التي تواجه الباحثين في هذا الموضوع هي تحديد طبيعة هذه العوامل من الوجهة السيكولوجية، وتصنيفها في إطار القدرات العقلية أو في إطار السمات المزاجية، لأنه

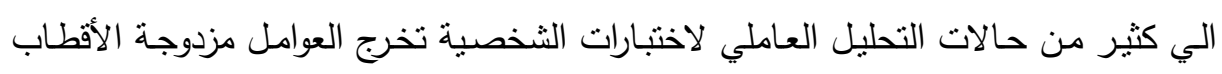

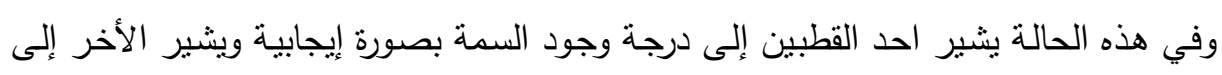
الدرجة التي توجد بها عكس هذه السمة من هذا القبيل العامل الذي يمتد من قطب الانطواء

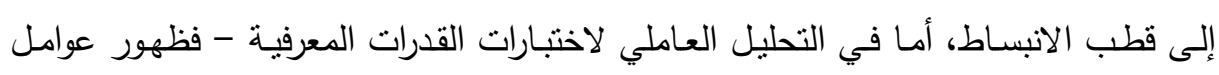

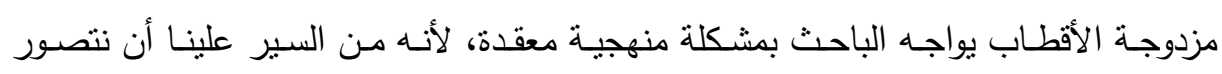

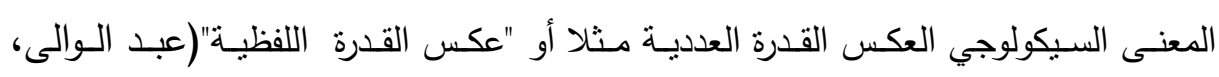

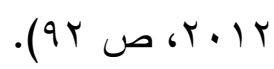

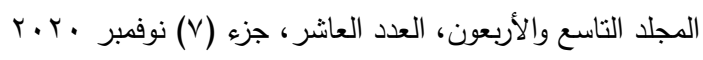

$$
\begin{aligned}
& \text { التزقيم الدولي }
\end{aligned}
$$


وبناء على ذللك فان مشكلة تفسير العوامل تقسيرة سيكولوجية تنقى قائمسة من الوجهة المنهجية، فبعض العوامل التي أقرها الباحثون على أنها عقلية تبقى مزدوجة القطب مثنلا .

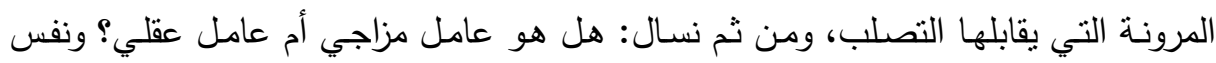

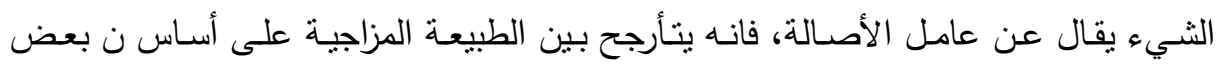

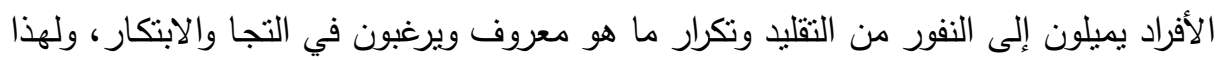

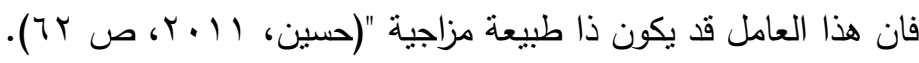
أبعاد الأداء الإداري: يتضمن الأداء عدة أبعاد متداخلة منها ما يلي: - العمل الذبي يؤديه الفرد - الانجازات التي يحققها الفرد في عمله - سلوك الفرد في وظيفته وتجاه زملائه ورؤسائه - الحالة النفسية والمزاجية التي يوجد عليها الفرد - طرق التحسين والتطوير التي يسلكها الفرد ليزيد من كفاءة

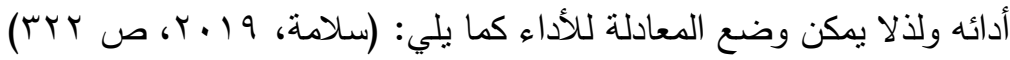
الأداء = القدرة على العمل به الرغبة في العمل × البيئة أولا: القدرة على العمل: ونقصد بالقدرة هنا أن يستطيع الفرد أداء العمل الموكل إليه بالدرجة

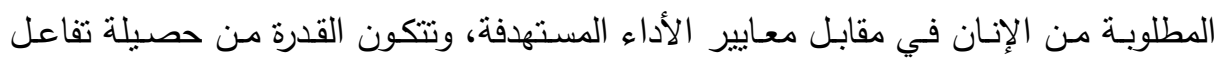

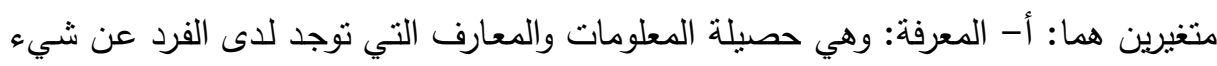

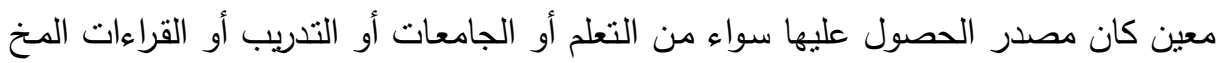

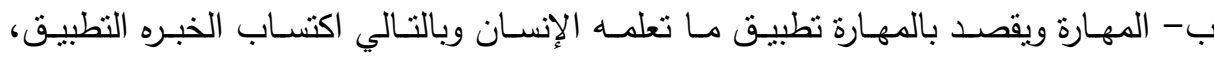

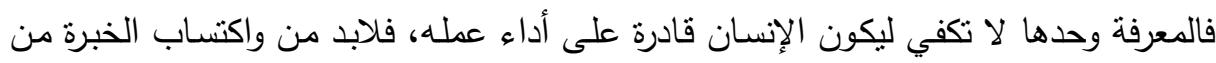

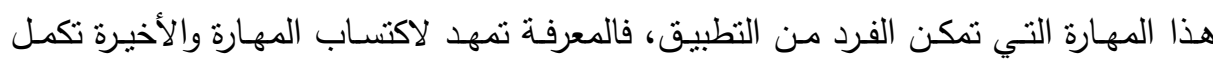

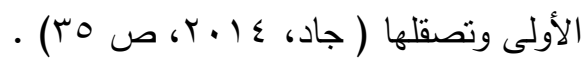
ثانياً: الرغبة في العمل_يتعلق الرغبة بدوافع الفرد وهي أصعب من القدرة، سواء في تكوينها

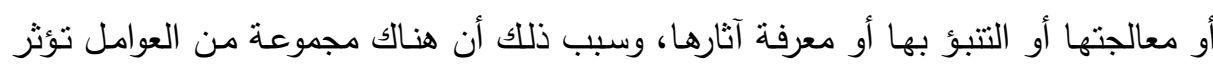
على دوافع الفرد منها نكوينه الثخصي، الوظيفة التي يؤديها، جماعة العمل التي يعمل معها، 406

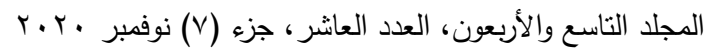

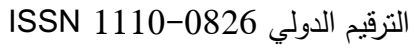


ظروف العمل، مدى إثباع حاجاته والظروف الاقتصادية والاجتماعية وعنصر الزمن. وتتكون

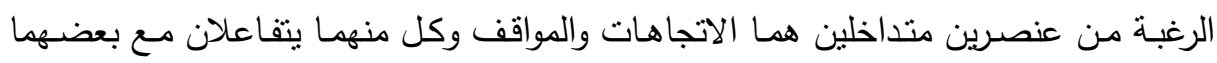

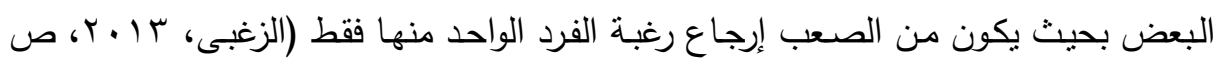

ثالثا :البيئة: بالإضافة إلى العاملين السابقين (القدرة على العمل والرغبة في العمل فلابد من دراسة البيئة المحيطة بهم ويقصد بالبيئة الحيطة مجموعة من العوامل البيئة الداخلية، البيئة المباشرة، البيئة الخارجية) ا- عوامل البيئة الداخلية : وتمتل كافة الطاقات والاحتياجات المادية والإنسائية والمالية الحالية والمستقبلية وكذللك قيم وفلسفة أفراد الإدارة والتي نؤثر إلى حد كبيرة

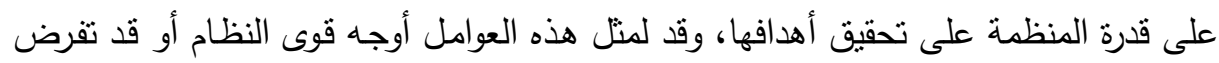

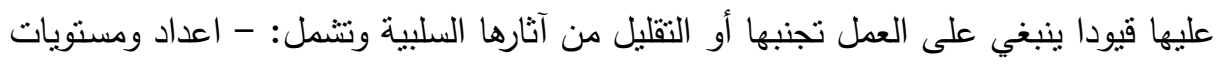

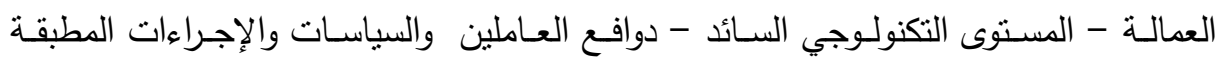
وتدخل هذه العوامل إلى حد كبير في نطاق رقابة وسيطرة المنظمة (سيوف، (919) (1).

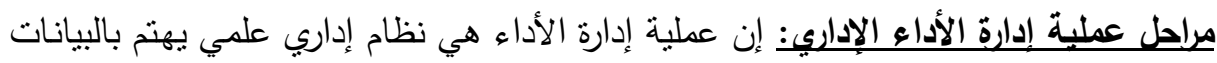

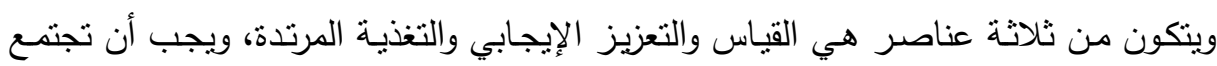

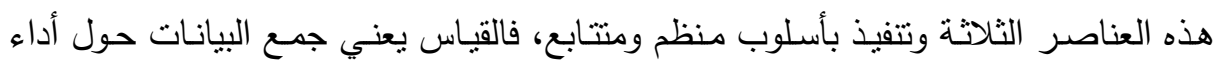

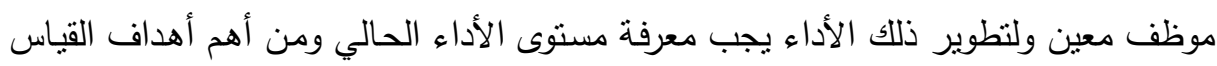

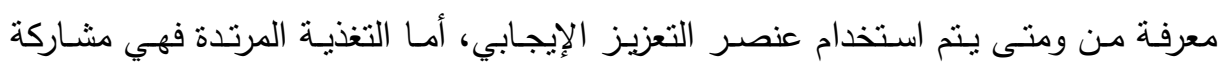

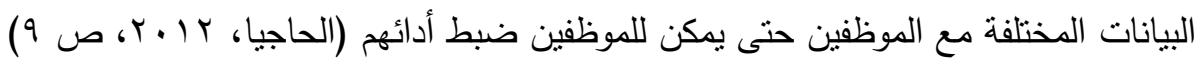

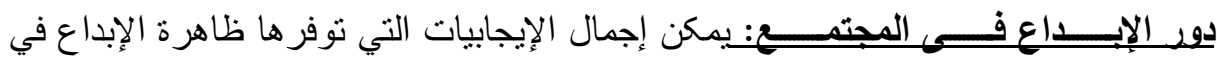
النتظيمات على النحو النالي:

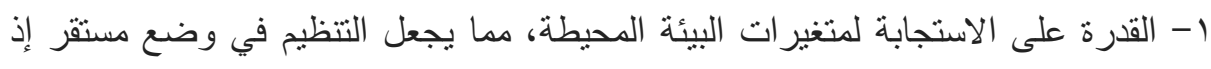
يكون لايه الاستعداد لمواجهة هذه التغيرات بشكل لا يؤثز على سير العطليات 
r- تحسين خدمات التنظيم بما يعود بالنفع على التنظيم و الفرد.

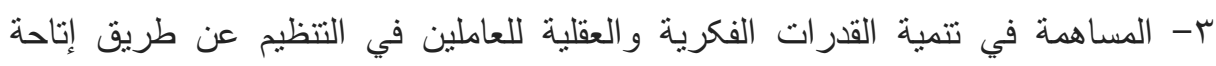
الفرصة لهم في اختبار تلك القدرات. - الاستغلال الأمتل للموارد المالية عن طريق استخدام أساليب علمية نتواكب مع

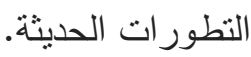
ع- القدرة على إحداث التو ازن بين البر امج الإنمائية المختلفة و الإمكانيات المادية و البشرية

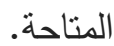
ه- حسن استغلال الموارد البشرية والاستفادة من قدراتهم عن طريق إتاحة الفرصة لها في

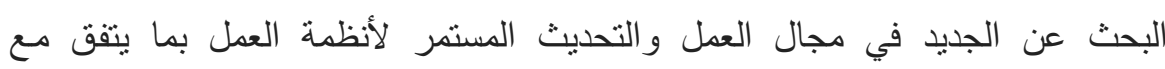

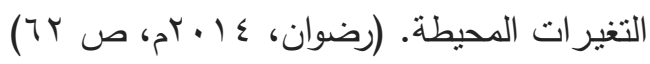

طبيعة التنمبة المستـامة: التتمية المستدامة :هي عملية نطوير الأرض والمدن والمجتمعات وكذللك الأعمال التجاريـة بشرط ان تلبي احتياجـات الحاضـر بدون المسـاس بقدرة الأجيال

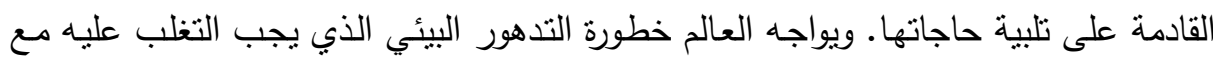

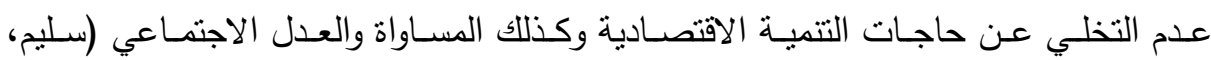

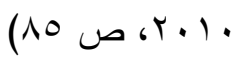

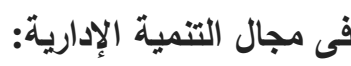
تضخم الجهاز الإدارى للاولة التعقيدات الادارية والمكتبية.

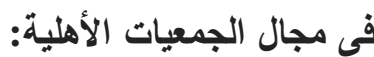

- قلة الاعتمادات الم صصة للمنظمات غير الحكومية خانة العاملة في مجال حماية البيئة. - القصور في التعاو بية الجمعيات الأهلية والحكومة -.غياب وضعف التتسيق فيما بية

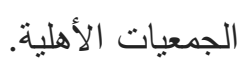

- ضعف المشاركة الشعبية فى نشاط الجمعيات الأهلية. 408

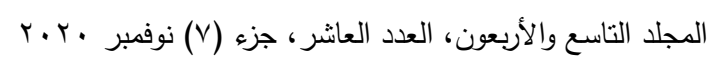

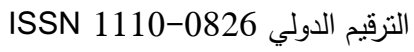


- قصور وساةل الإعلم في الاهتمام بالمنظمات غير الحكومية وأنشطتها.

- - صعوبة وصول الجمعيات الأهلية العاملة في مجال حماية البيئة إلى المعلومات البيئية. - - الحاجة إلى بناء القدرات في المجال الإدار والمهارات الفنية للجمعيات الأهلية

\section{همطلحايه الصراسلة}

تتاولت الدراسة مجموعة من المصطلحات أهمها ( التفكير المنطقي ، الموقف الابداعي

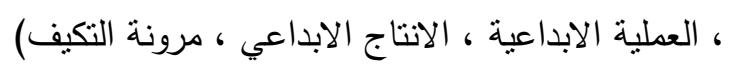

() التفكير المنطقي: وهو قدرة الفرد على معرفة العوامل ذات العلاقة والإرتباط بالمشكلة والعوامل التي ليس لها ارتباط بالمشكلة، كما يعني الانتقال بشكل منسلسل في خطوات حل

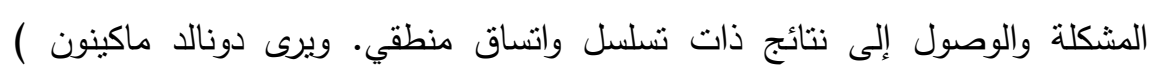

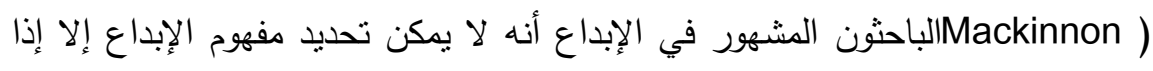

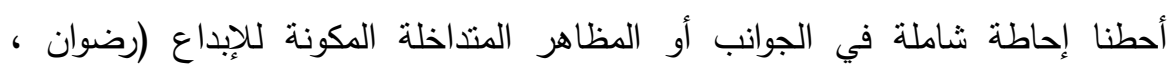
$\cdot(r \cdot) \leq$ r) الموقف الابداعي: إن تكرار المواقف الإبداعية وتعددها يسهم بإطلاق صفة المبدع

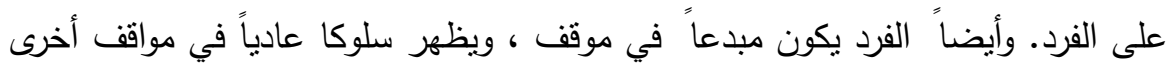

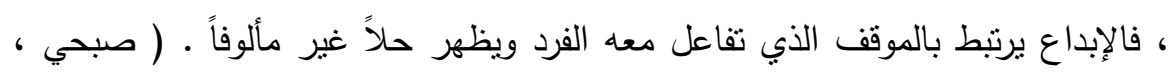

r) العملية الابداعية: هي عملية معرفية ذهنية ، حيث يكون الفرد في هذه العملية نشطا منظما للخبرات لكي يستجيب للموقف الجديد ، تعددت النظرة للشخص المبدع بسبب تعدد زوايا النظر ، فبعضهم يركز على الجوانب الأدائية وآخرين على الجوانب الذهنية .

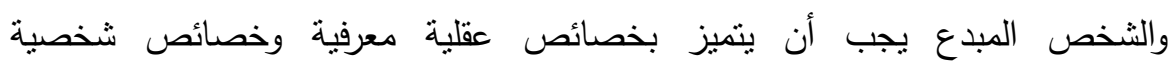

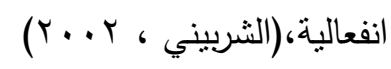

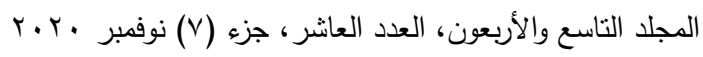

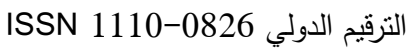


ء) الانتاج الابداعي: هو أحد جوانب تفاعل الإنسان مع البيئة ويقاس الإبداع في أحد

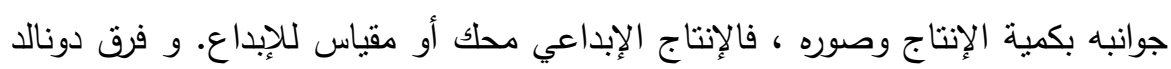
تيلر ( D.W. Taylor ) بين التفكير الإبداعي وحل المشكلات واتخاذ القرار بناء على لئل الإنتاج : فحل المشكلات هو ذللك النوع من التقكير الذي ينتج عنه حل للمشكلات.

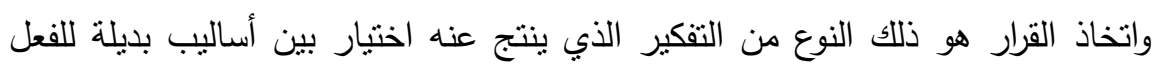

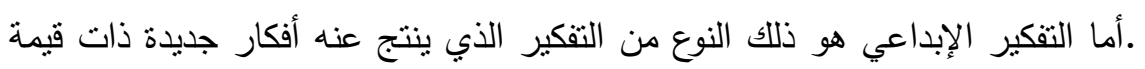
ويقول تورانس ( Torrance ) أن الطفل أكثر إبداعا من الراشد، وأكثر سنوات الطفل

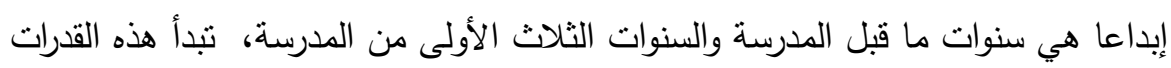

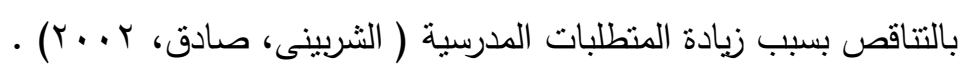

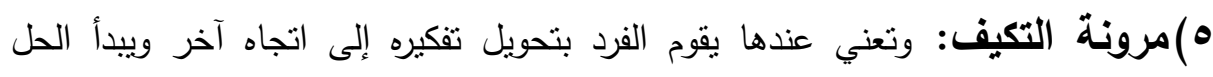
بطريقة أخرى قد توصله إلى الحل النهائي وكذللك المرونة التلقائية : وتنشير إلى سرعة إنى الفرد في إعطاء استجابات متتوعة نتتمي إلى اتجاه واحد أو مظهر واحد. (الرواشدة ،

\section{اجزاعايت الهيهث}

منهج البحث: اعتمد البحث على المنهج الوصفى في الدراسة النظرية واعداد الجانب الميداني على قائمة الاستيان الموجهة لمفردات العينة والتي تبلغ ل . F مفردة وتم استخدام التحليل

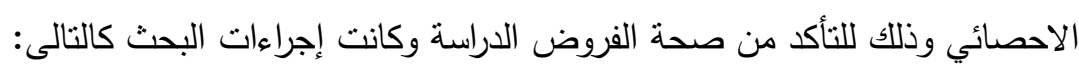

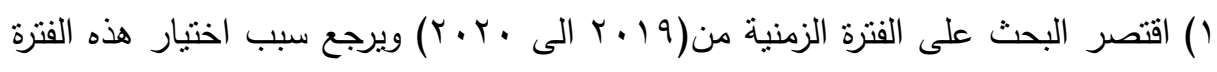

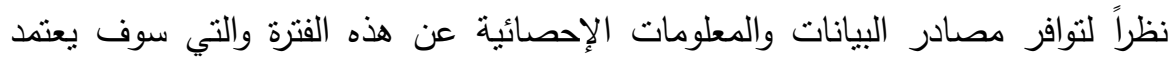
عليها الباحثون

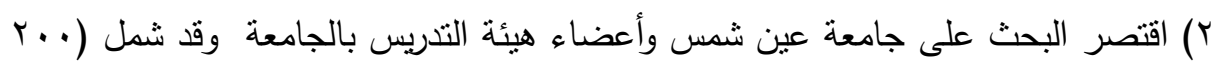

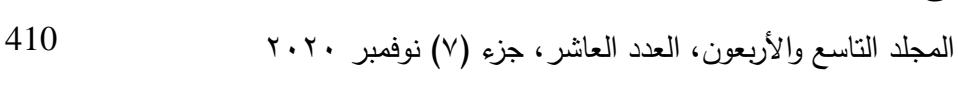

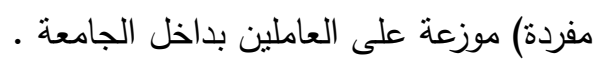

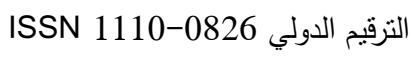




$$
\begin{aligned}
& \text { مجلة العلوم البيئية } \\
& \text { معهد الدراسات والبحوث البيئية - جامعة عين شمس بـ } \\
& \text { رانده جمال عبدالمنعم وآخرون }
\end{aligned}
$$

ثم بعد ذللك نم تضمنين لجزء تحليل البيانات باستخدام بعض الأساليب والاختبارات الإحصائية للتحقق من صحة فروض الدراسة المنبنقة عن الأهداف العامة للرسالة، وذللك لقياس دور الإبداع فى رفع مهارات الايدى العاملة وتحقيق التتمية المستدامة. وتم تحليل البيانات على عدة مراحل وهي كما يلي: 1. إدخال وترميز البيانات.

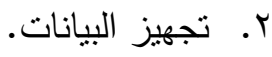
r. التعرف على واستكثاف خصائص عينة الدراسة. ـ. إجراء الاحصاء الوصفي لمتغيرات الدراسة.

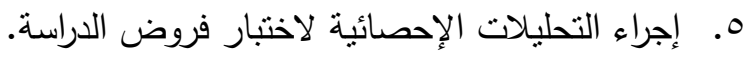

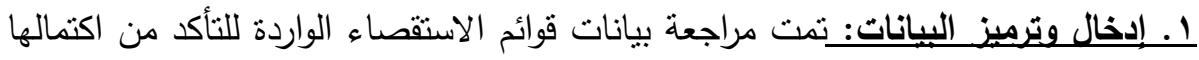
وصلاحيتها لإجراء التحليلات الإحصائية اللازمة، ومن ثم تم ترميز قيم جميع العبارات (الأسئلة) الواردة بنلك القوائم وتفريغها على الحاسب الآلي باستخدام كلاً من برنامج

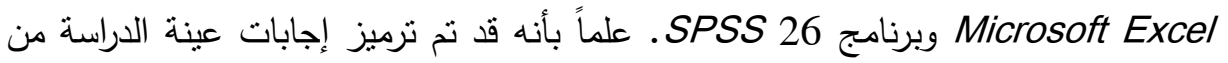
خلال إعطاء مجموعة من الأوزان التي يعبر كلاً منها عن الآراء المختلفة لعينة الدراسة وفئاً

\begin{tabular}{|c|c|}
\hline الوزن & الآراء \\
\hline 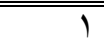 & لا آوافق بشدة \\
\hline r & لا أوافق \\
\hline r & محايد \\
\hline$\varepsilon$ & موافق \\
\hline 0 & موافق بشدة \\
\hline
\end{tabular}

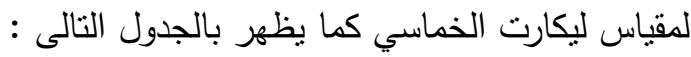

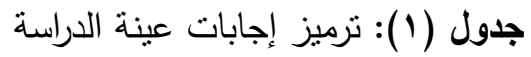

r. تجهيز البيانات: عند جمع البيانات الأولية من قوائم الاستقصاء (الاستبيان) فإن تجهيز

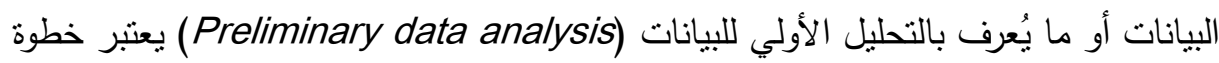
أساسية ومطلوبة قبل إجراء التحليلات الإحصائية اللاحقة. حيث أن التحليل الأولي للبيانات

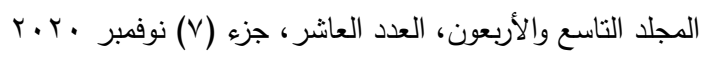

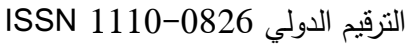


يُعد أمراً بالغ الأهمية للتأكد من أن التحليلات الإحصائية اللاحقة سوف نتم بشكل صحيح. وقد تأسست عملية التحليل الأولي للبيانات من المراحل التالية:

1. إجراء اختبارات الثبات والصدق (Reliability and Validity tests). r . تحديد الأساليب الاحصائية المستخدمة في تحليل البيانات.

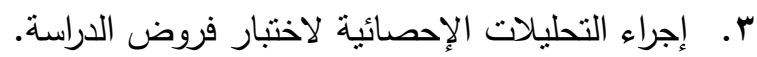

r r ـ ـ إجراء اختباري الثبات والصدق (Reliability and Validity tests): ينم إجراء كلاً من اختباري الثبات Reliability والصدق Validity عادةً بهدف معرفة مدى صدق وصحة

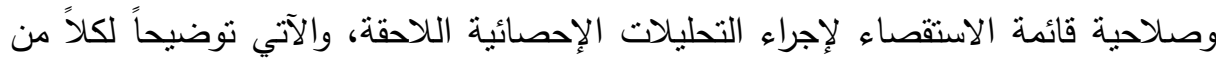
معاملي الثبات والصدق. معامل الثبات Reliability: الثبات يُشير إلى مدى استقرار عبارات (بنود) قائمة الاستقصاء وعدم تتاقضها مع نفسها، أي أن قائمة الاستقصاء سوف تُعطي نفس النتائج نقريباً باحتمال

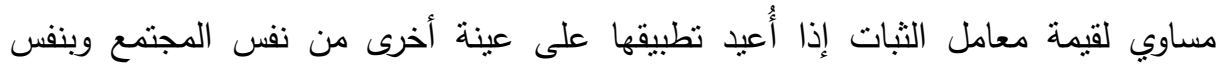
الحجم. ولإجراء اختبار الثبات للعبارات الواردة بقوائم الاستقصاء تم استخدام معامل ألفا لهاء

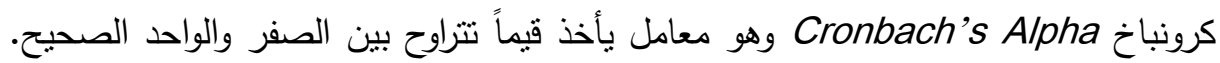

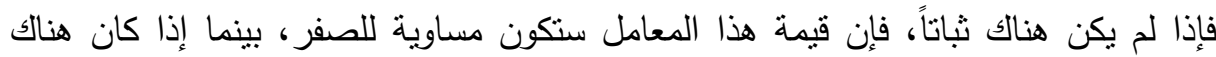

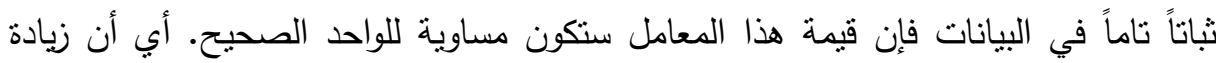

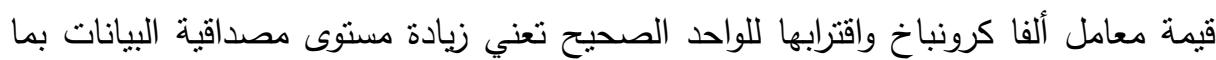

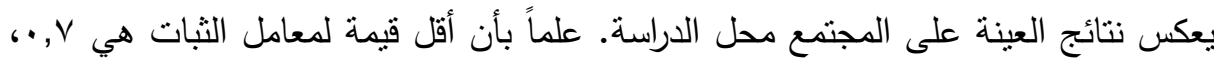

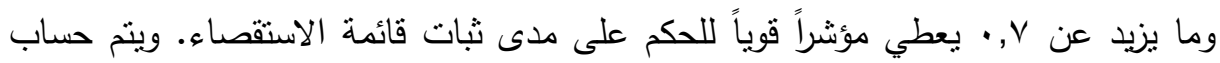

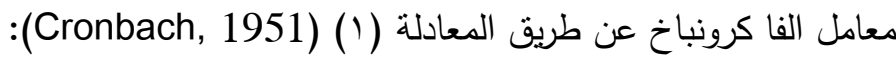

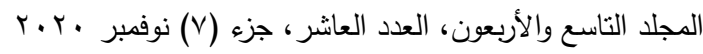

$$
\begin{aligned}
& \text { التزقيم الدولي 0826-0 التون، }
\end{aligned}
$$




\section{مجلة العلوم البيئية \\ معهد الدراسات والبحوث البيئية - جامعة عين شمس لئس \\ رانده جمال عبدالمنعم وآخرون}

$$
\begin{aligned}
\text { Alpha }=\frac{n}{n-1} & (1 \\
& \left.-\frac{\sum_{i=1}^{n} V_{i}}{V_{t}}\right)
\end{aligned}
$$

حيث أن:

Alpha

n ترمز إلى عدد العبارات الواردة بقائمة الاستقصاء. ترمز

ت نرمز إلى تباين جميع العبارات بقائمة الاستقصاء.

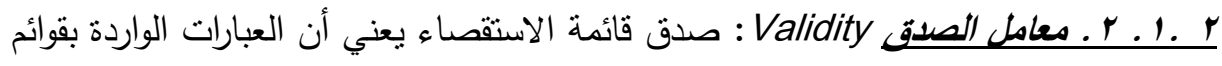

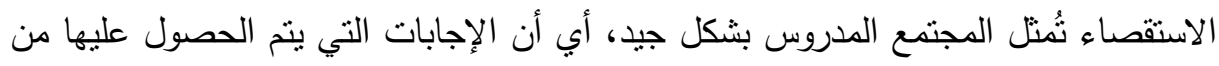
قوائم الاستقصاء تعطي المعلومات التي وضعت من أجلها العبارات (قائمة الاستقصاء تقيس الاجبات ما وضعت لقياسه). ويتم قياس معامل الصدق عن طريق أخذ الجزر التربيعي لمعامل الثبات

\section{Validity}

كما هو موضح بالمعادلة (2).

$=\sqrt[n]{\text { Alpha }}$

والجدول (Y) يوضح نتائج نطبيق كلاً من اختباري الثبات والصدق على مستوى متغيرات

\begin{tabular}{|c|c|c|c|}
\hline معامل & معامل & عدد العبارات & المتغيرات (الأبعاد) \\
\hline$\cdot, 9.7$ & $\cdot, \Lambda Y$. & $1 \pi$ & الإبداع (X) \\
\hline$\cdot, \mathrm{A} \vee \mathrm{I}$ & $\cdot, \vee \vee 09$ & $\mathrm{~V}$ & مهارات الإبدى العاملة (Y1) \\
\hline$\cdot$, , Ат & $\cdot, \mathrm{VO}$ & TY & تحقيق التتمية المستدامة (Y2) \\
\hline
\end{tabular}

جدول (ץ): نتائج تطبيق معاملي الثبات والصدق

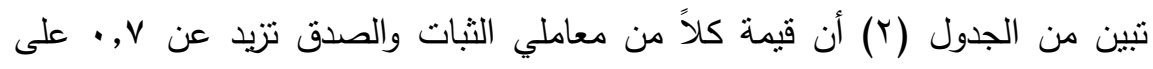

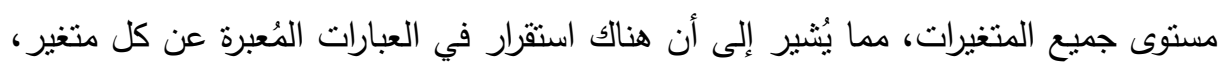

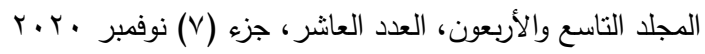

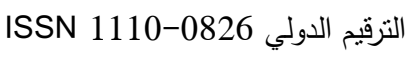


كما أن قائمة الاستقصاء تقيس ما وضعت لقياسه، وبالتالي فإنها تُمتل مجتمع الدراسة بشكل جيد، لذلك يمكن الاعتماد على بيانات تللك القائمة في عمل التحليلات والاختبارات الإحصائية ولئية

اللاحقة.

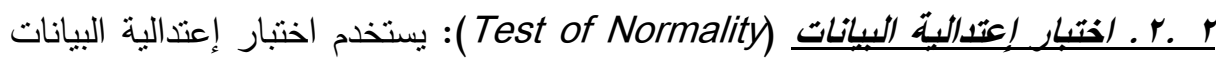

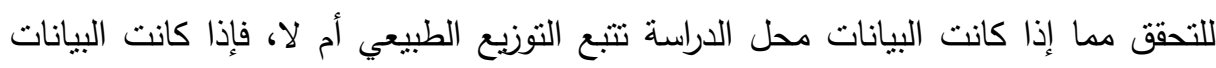

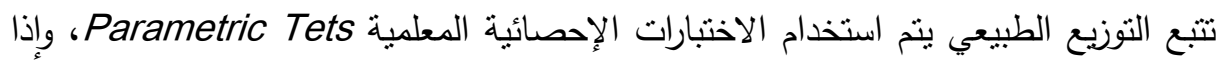

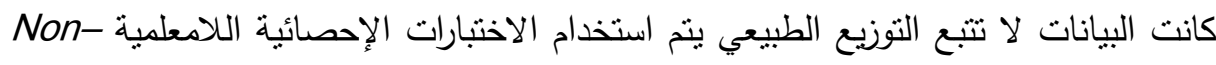
Parametric tests

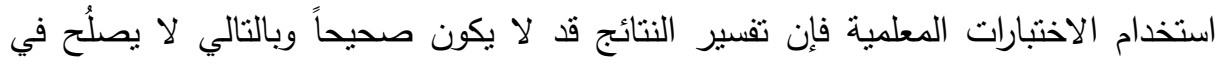

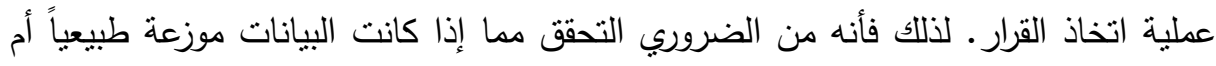
لا، وبناءً عليه يتم تحديد الاختبارات الإحصائية المناسبة لتحليل البيانات واختبار الفروض. وجديراً بالذكر أنه نوجد مجموعة من الطرق والاختبارات الاحصائية التي تُشتخدم في معرفة ما

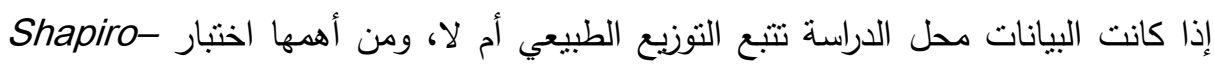
Wilk

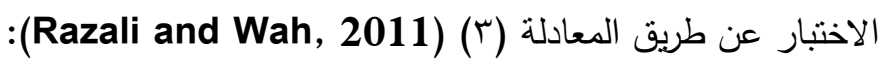

W

$=\frac{\left(\sum_{i=1}^{n} a_{i} y_{i}\right)^{2}}{\sum_{i=1}^{n}\left(y_{i}-\bar{y}\right)^{2}}$

$$
\begin{aligned}
& \text { حيثُ أن: } \\
& \text { — } y_{i} \\
& \text { ๘ } \bar{y}
\end{aligned}
$$

× $a_{i}$ التوزيع الطبيعي المعياري.

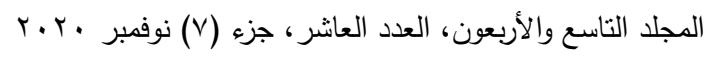

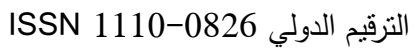


والجدول (r) يوضح نتيجة اختبار إعتدالية البيانات (اختبار Shapiro-Wilk) على

مستوى متغيرات وأبعاد الدراسة.

جدول (ץ):اختبار إعتدالية البيانات باستخدام اختبار Shapiro-Wilk

\begin{tabular}{|c|c|c|c|}
\hline \multirow{2}{*}{ (الإعبدالية) } & \multicolumn{2}{|c|}{$\begin{array}{c}\text { Shapiro-Wilk } \\
\text { Sirolk }\end{array}$} & \multirow{2}{*}{ المتغيرات (الأبعاد) } \\
\hline & القيمة الاحتماليةة & قيمة هُ الاختبار & \\
\hline غير معتدل & $\cdot, \cdots$ & $\cdot, 9.9$ & الإبـاع (X) \\
\hline غير معتدل & $\cdot, \ldots$ & $\cdot, 9 \leq \mu$ & مهارات الايدى العاملة (Y) \\
\hline غير معتدل & $\cdot, \ldots 1$ & $\cdot, 9 \vee r$ & تحقيق التنميةٌ المستدامةُ (Y) \\
\hline
\end{tabular}

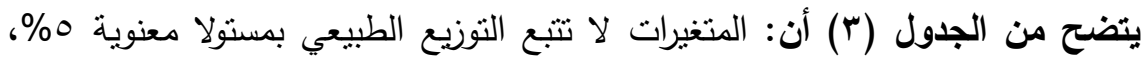
حيث ان القيمة الاحتمالية لاختبار Shapiro-Wilk نقل عن قيمة مستوى المعنوية المعياري

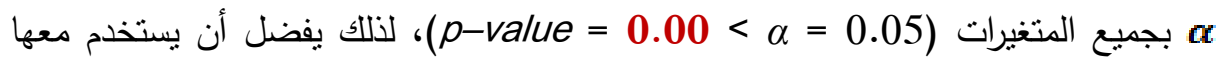
الاختبارات الاحصائية اللامعلمية (Non-Parametric tests). وبناء على ما سبق سوف يتم الاعتماد عند إجراء التحليلات الاحصائية اللاحقة على الاختبارات اللامعلمية. وبهذا يكون

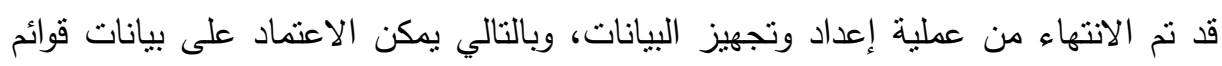

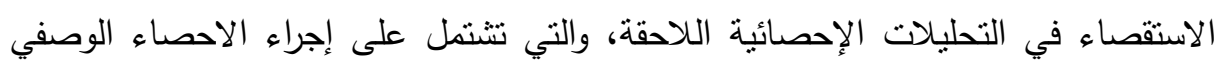

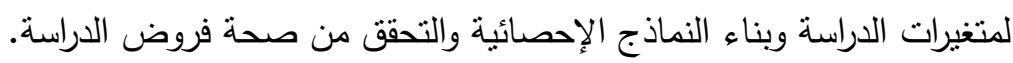

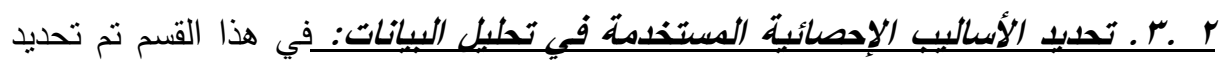
الأساليب والاختبارات الإحصائية التي سوف تستخدم في عملية التحليل الاحصائي للبيانات

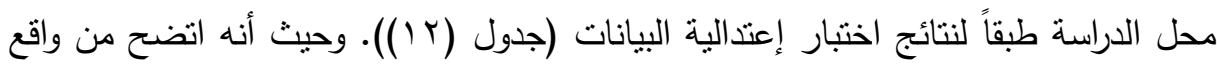
النتائج أن المتغيرات لا تتبع التوزيع الطبيعي، فقد قام الباحث باستخدام الاختبارات الإحصائية 
1. إجراء الاحصاء الوصفي Descriptive Statistics عن طريق حساب الوسط الحسابي Standard لقياس منوسط آراء المستقصى منهم وحساب الانحراف المعياري Mean Deviation (SD)

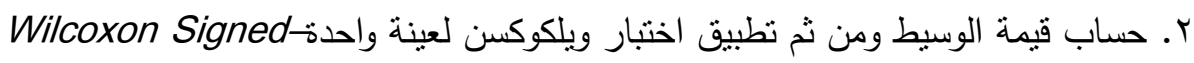
Rank test

$$
\text { الدراسة بالقيمة ب والتي تعبر عن وسيط الأوزان (محايد). }
$$

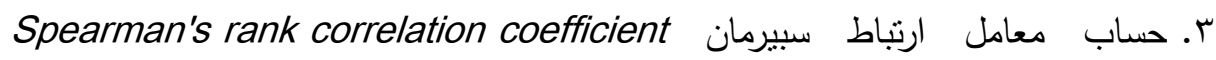
اللامعلمي لمعرفة ما إذا كانت هناك علاقة بين المتغيرات المستقلة والمتغيرات التابعة أم

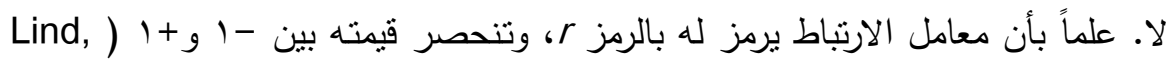

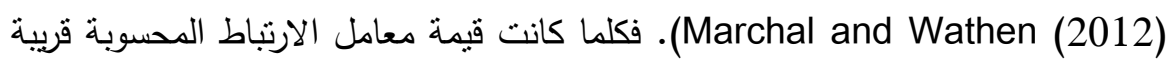
من الواحد الصحيح (بغض النظر عن الإثارة) كلما دل ذللك على قوة العلاقة بين

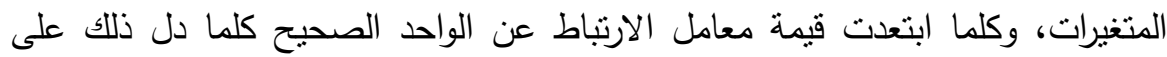

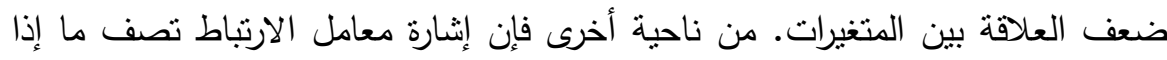

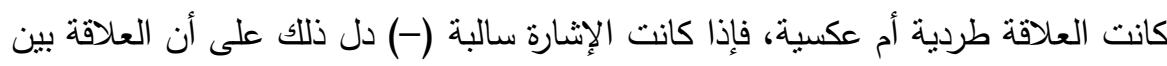

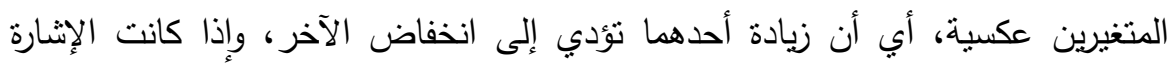

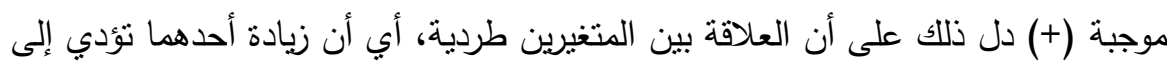
زيادة الآخر (المتغيرين يتحركان في نفس الاتجاه). ع. إذا تبين أن هناك علاقة بين المتغيرات المستقلة والمتغيرات التابعة يتم تطبيق تحليل الانحدار الخطي البسيط Simple Linear Regression كخطوة ثانية لدراسة تأثير المتغيرات المستقلة على المتغيرات التابعة.

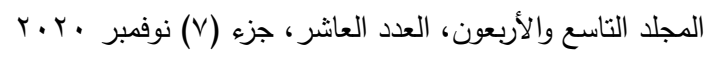

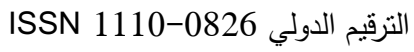


r. التعرف على واستكشاف خصائص عينة الدراسة: نم حساب التكرارت المطلقة والنسبة

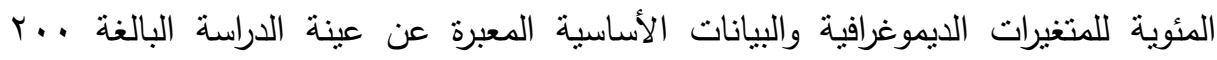
مفردة، بهدف التعرف على واستكثاف خصائص عينة الدراسة كما هو موضح بالجدول التالى: جدول ( ) : التكرارات المطلقة والنسبة المئوية للبيانات الديموغرافية

\begin{tabular}{|c|c|c|c|}
\hline النسبة المئوية (\%) & التكرارات المطلقة & العناصر & المتغيرات \\
\hline$r, 0$ & 0 & بدون شهادة & \multirow{3}{*}{ الحالة التعليمية } \\
\hline YI,0 & $\varepsilon r$ & مؤهل متوسط & \\
\hline VI & $10 Y$ & جامعي & \\
\hline 0 & 1. & أقل من • " سنة & \multirow{4}{*}{ 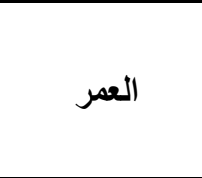 } \\
\hline$M$ & $7 r$ & من ·r - . ع سنة & \\
\hline$\varepsilon r$ & 17 & من ، ع - .0 سنة & \\
\hline YI & $\varepsilon r$ & . & \\
\hline$\cdot$ & $\cdot$ & ريف & \multirow{2}{*}{ محل الإقامة } \\
\hline $1 \ldots$ & $r \ldots$ & حضر & \\
\hline$\cdot$ & $\cdot$ & فيلا & \multirow{3}{*}{ طبيعة المسكن } \\
\hline $1 \ldots$ & $r \ldots$ & شقة & \\
\hline . & $\cdot$ & حجرة & \\
\hline $1 \cdots$ & $r \ldots$ & منزوج/ منزوجة & \multirow{2}{*}{ الاجتماعية } \\
\hline$\cdot$ & $\cdot$ & غير منزوج/ غير منزوجة & \\
\hline
\end{tabular}

ـ ـ إجراء الاحصاء الوصفي لمتغيرات الدراسة: نم إجراء الاحصاء الوصفي لمتغيرات الدراسة عن طريق حساب الوسط الحسابي والانحراف المعياري، وذلك لمعرفة الاتجاه العام للأراء

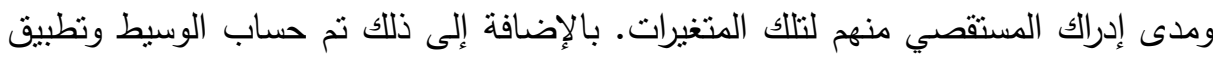

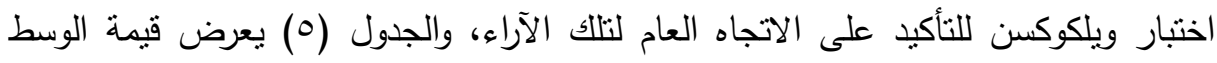
الحسابي، والانحراف المعياري، والوسيط ونتيجة اختبار ويلكوكسن على مستوى متغيرات 
مجلة العلوم البيئية

معهد الدراسات والبحوث البيئية - جامعة عين شمس لهنه

رانده جمال عبدالمنعم وآخرون

جدول (0):الإحصاء الوصفي واختبار ويلكوكسن

\begin{tabular}{|c|c|c|c|c|}
\hline ويلكوكسن & \multicolumn{3}{|c|}{ الإحصاء الوصفي } & \multirow[b]{2}{*}{ المتغيرات } \\
\hline $\begin{array}{c}\text { الاحتمالية } \\
\text { p-value }\end{array}$ & الوسيط & المعياري & الحسابي & \\
\hline$\cdot, \cdots$ & $\varepsilon, 0$ & $\cdot$, r ז & $\varepsilon, \varepsilon V$ & الإبداع(X) \\
\hline$\cdot, \ldots$ & $\varepsilon, \varepsilon$ & $\cdot, \varepsilon r q$ & $\varepsilon, \mu$ & مهارات الايدى العاملة(Y1) \\
\hline$\cdot, \ldots$ & $\varepsilon, \Gamma$ & $\cdot, \Sigma Y Y$ & $\varepsilon, 1 \mathrm{~V}$ & تحقيق التتمية المستدامة(Y2) \\
\hline
\end{tabular}

ا. يميل الاتجاه العام لآراء عينة الدراسة إلى الموافقة على جميع عبارات الإبداع، حيث أن قيمة الوسط الحسابي البالغة V乏,؛ نزيد عن القيمة r، وقد جاءت نتيجة اختبار ويلكوكسن لتؤكد ذلك، حيث تبين أن قيمة الوسيط البالغة ه,ـ تزيد عن ب، كما أن القيمة الاحتمالية لاختبار ويلكوكسن نقل عن قيمة مستوى المعنوية $\alpha$ )

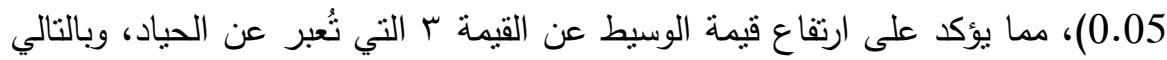
نخلُص من واقع اختبار ويلكوكسن إلى أن آراء عينة الدراسة تُشير إلى المونى الموافقة على على الإبداع.

r. يميل الاتجاه العام لآراء عينة الدراسة إلى الموافقة على جميع عبارات مهارات الايدى

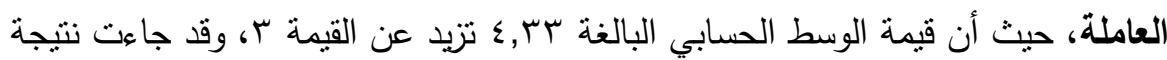

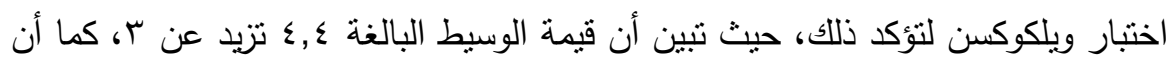

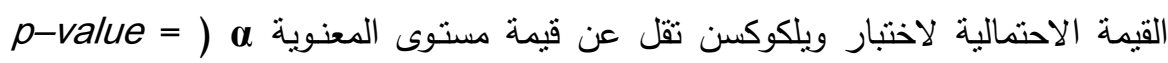
0.05

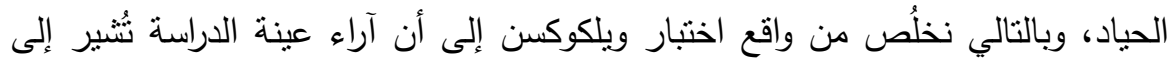
الموافقة على مهارات الايدى العاملة. r. يميل الاتجاه العام لآراء عينة الدراسة إلى الموافقة على جميع عبارات تحقيق التنمية

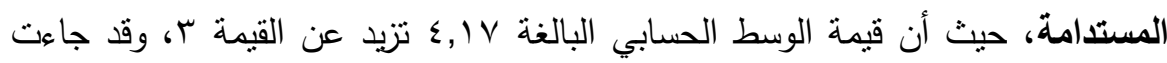
418

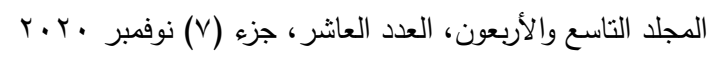

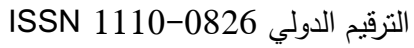


نتيجة اختبار ويلكوكسن لتؤكد ذلك، حيث تبين أن قيمة الوسيط البالغة r,؛ تزيد عن س،

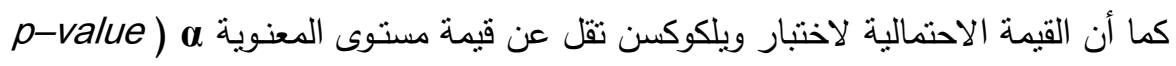

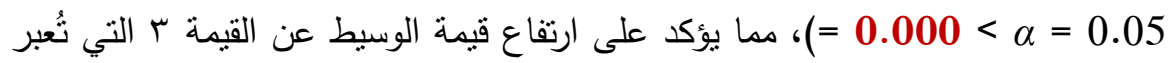
عن الحياد، وبالتالي نخلُص من واقع اختبار ويلكوكسن إلى أن آراء عينة الدراسة تُشير التير إلى الموافقة على تحقيق التتمية المستدامة. ه. إجراء التحليلات الاحصائية لاختبار فروض الدراسة: في هذا القسم تم إجراء مجدوعة من التحليلات الإحصائية لاختبار فروض الدراسة الرئيسية الأتية: ( ) لا توجد علاقة ذات دلالة إحصائية بين الإبداع ومهارات الايدى العاملة. r) لا توجد علاقة ذات دلالة إحصائية بين الإبداع وتحقيق التتمية المستدامة.

\section{نمائي اللهمهث}

جدول ( ) : نتائج تطبيق معاملي الثبات والصدق قبل البدء فى إجراء الإحصاءات

\begin{tabular}{|c|c|c|c|}
\hline الصدامل & معامل & عدد العبارات & المتغيرات (الأبعاد) \\
\hline$\cdot, 9.7$ & $\cdot, \Lambda Y$. & $\pi$ & الإبداع (X) \\
\hline$\cdot, \wedge \vee 1$ & $\cdot, \mathrm{V} \circ 9$ & $\mathrm{~V}$ & مهارات الأيدي العاملة (Y) \\
\hline$\cdot, \wedge 77$ & $\cdot, \mathrm{V} 0$. & 14 & تحقيق التنمية المستدامة (Y2) \\
\hline
\end{tabular}

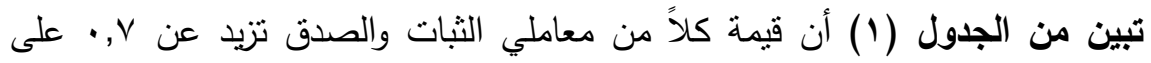

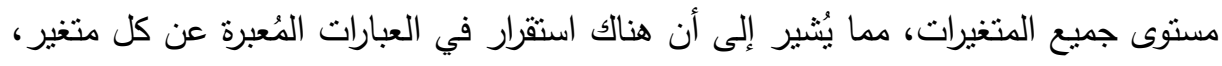

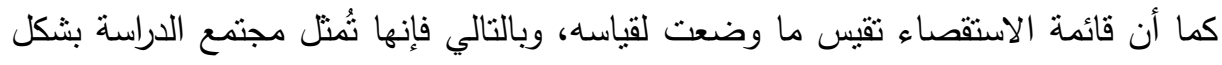
جيد، لذلك يمكن الاعتماد على بيانات نللك القائمة في عمل التحليلات والاختبارات الإحصائية 
مجلة العلوم البيئية

معهد الدراسات والبحوث البيئية - جامعة عين شمس لهنه

رانده جمال عبدالمنعم وآخرون

جدول (ץ): مصفوفة الارتباط بين الإبداع ومهارات الايدى العاملة

\begin{tabular}{|c|c|c|c|}
\hline$Y_{1}$ & $\bar{x}$ & \multicolumn{2}{|c|}{ المتغيرات } \\
\hline - rYA & \multirow{2}{*}{1} & الارتباط & \multirow{2}{*}{ الإلإداع } \\
\hline$\cdot, \ldots$ & & $p$-value & \\
\hline \multirow{2}{*}{1} & • TYM & الارتباط & \multirow{2}{*}{ مهارات الايدى العاملة } \\
\hline & $\cdot, \ldots$ & $p$-value & \\
\hline
\end{tabular}

يتضح من الجدول أن: هناك علاقة ارتباط طردية (ايجابية) منخفضة ذات دلالة

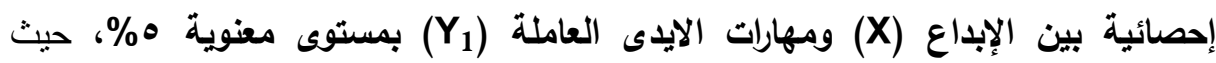

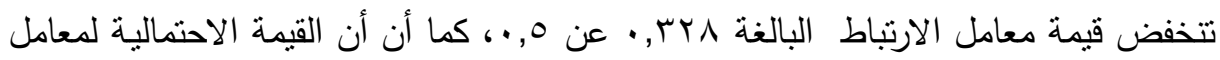
الارتباط تقل عن قيمة مستوى المعنوية $\alpha$ (palue = $0.000<\alpha=0.05)$. وكمحلة نهائية، يكون لدينا مؤشر مبدئي على إمكانية ظهور تأثنير للإبداع على مهارات الايدى العاملة. لذلك تم تطبيق تحليل الانحدار الخطي البسبط لمعرفة حقية هذا التأثنر. جدول (r): مصفوفة الارتباط بين الإبداع ومهارات الأيدي العاملة

\begin{tabular}{|c|c|c|c|}
\hline Y1 & $\bar{X}$ & & المتغيرات \\
\hline • & \multirow{2}{*}{1} & الارتباط & \multirow{2}{*}{ الإبداع (X) } \\
\hline$\cdot, \cdots$ & & $p$-value & \\
\hline \multirow[b]{2}{*}{1} & •, rYA & الارتباط & \multirow{2}{*}{ مهارات الأيدي العاملة(Y1) } \\
\hline & $\cdot, \cdots$ & $\begin{array}{c}\text { p- } \\
\text { value }\end{array}$ & \\
\hline
\end{tabular}

يتضح من الجدول أن: هنآك علاقة ارتباط طردية (ايجابية) منخفضة ذات دلالة

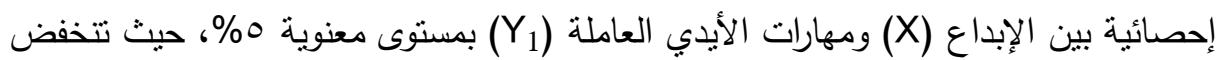

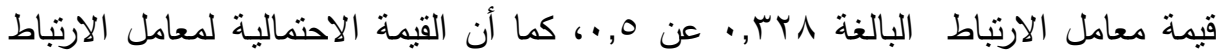
تقل عن قيمة مستوى المعنوية d (p-value = 0.000 (p=05). وكمحصلة نهائية، يكون لدينا مؤشر مبدئي على إمكانية ظهور تأثنر للإبداع على مهارات الأيدي العاملة. لذلك تم تطبيق تحليل الانحدار الخطي البسيط لمعرفة حقيقة هذا التأثير. 420

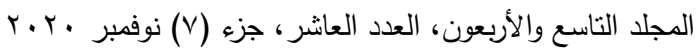

$$
\begin{aligned}
& \text { الترقيم الدولي 0826-1110 نوني }
\end{aligned}
$$




\section{ثانياً: الانحدار الخطي البسبط}

Coefficient of Correlation ) يوضح الجدول التالى نتيجة كلاً من معامل الارتباط النياط

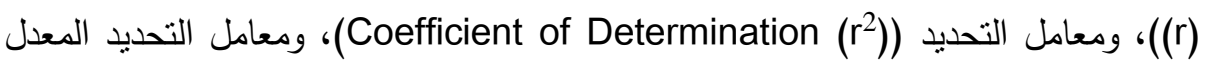
(Coefficient of Determination Adjusted (Adjusted $r^{2}$ )) للتقدير (Standard Error of the Estimate (S.E.)، بالإضافة إلى نتيجة اختبار بجدول تحليل التباين ANOVA table للتأكد من معنوية وأهمية نماذج الانحدار ككل. كما يوضح الجدول قيم معاملات الانحدار وقيمة معامل بيتا، ونتيجة اختبار t-test للتأكد من ون

معنوية المتغير المستقل المكون للنموذج. جدول (ع): ملخص نموذج الانحدار بين الإبداع ومهارات الأيدي العاملة

\begin{tabular}{|c|c|c|c|c|c|}
\hline \multicolumn{2}{|c|}{$\begin{array}{c}\text { جدول تحليل التباين } \\
\text { ANOVA }\end{array}$} & \multirow{2}{*}{ الخطأ المعياري } & \multirow{2}{*}{$\begin{array}{c}\text { معامل التحديد } \\
\text { (r2 Adjusted) }\end{array}$} & \multirow{2}{*}{$\begin{array}{l}\text { معامل } \\
\text { التحديد } \\
\text { (r2) }\end{array}$} & \multirow{2}{*}{$\begin{array}{c}\text { معامل } \\
\text { الارتباط } \\
\text { (r) }\end{array}$} \\
\hline الاحتمالية & F & & & & \\
\hline$\cdot, \cdots$ & $Y_{1}, V M T$ & $\cdot, \varepsilon \cdot \wedge q \vee$ & $\cdot, .9 \leq$ & $\cdot, .99$ & $\cdot, r) \leq$ \\
\hline
\end{tabular}

جدول (ه): اختبار t ومعاملات نموذج الاتحدار بين الإبداع ومهارات الأيدي العاملة

\begin{tabular}{|c|c|c|c|c|c|}
\hline \multicolumn{2}{|c|}{ اختبار } & \multirow{2}{*}{ مeta } & \multicolumn{2}{|c|}{ معاملات نموذج الانحدار } & \multirow{2}{*}{ لمتغيرات المستقلة } \\
\hline القيمة الاحتمالية & قِيمةٌ اختبار & & الخطأ المعياري & قيمة المعامل & \\
\hline$\cdot, \cdots$ & $\wedge, \cdot \wedge)$ & ---- & $\cdot, r \leq \cdot$ & r, $\vee 0$. & الثابت \\
\hline$\cdot, \cdots$ & $\varepsilon, 77 Y$ & $\cdot, r) \leq$ & $\cdot, \cdot \vee \vee 7$ & • ror & الإبداع \\
\hline
\end{tabular}

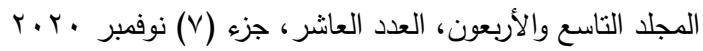

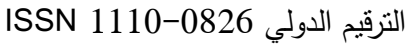


من الجدولين السابقين يتضح أن: الإبداع (X) يُعتبر متغير ذات دلالة إحصائية وله

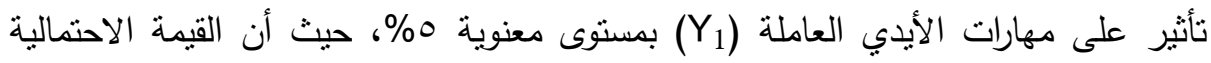

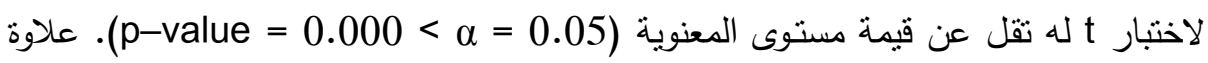

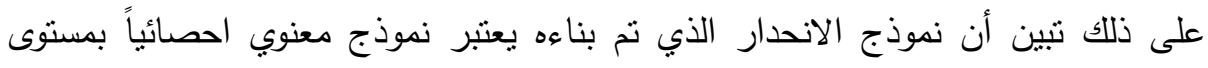
معنوية 0\%، حيث أن القيمة الاحتمالية لاختبار F تقل عن قيمة مستوى المعنوية المعياري

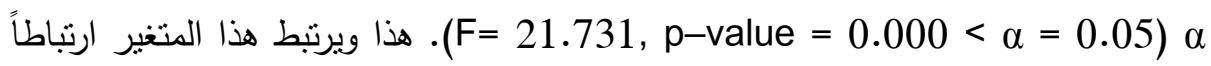

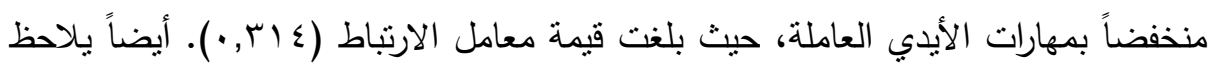
أنه يستطيع أن يُفسر ما يقرب من 9,9\% من التغيرات التي تطرأ على مهارات الأيدي

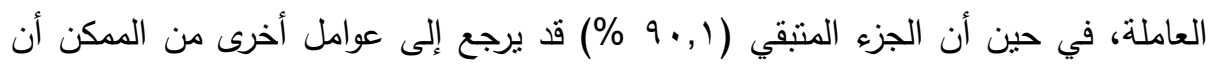

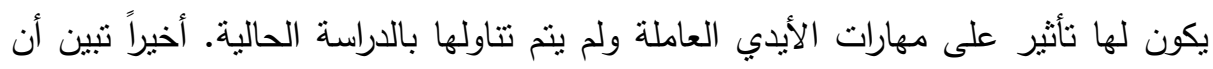

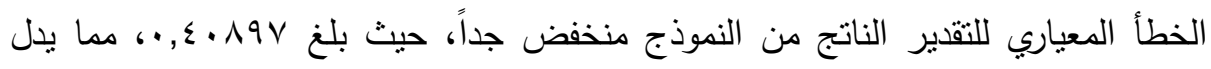
بالنهاية على جودة النموذج. وكمصلة نهائية من الجدولين السابقين تبين عدم صحة الفرض الأول القائل بأنه توجد علاقة ذات دلالة إحصائية بين الإبداع ومهارات الأيدي العاملة، نظراً لوجود تأثير الثاني لكلإبداع على مهارات الايدي العاملة.

يستعرض الباحثون فيما يلي أهم النتائج التي توصل اليها من خلال الدراسة التطبيقية لاراسة لاور الإبداع في رفع مهارات الأيدي العاملة لتحقيق التنمية المستدامة: () تظهر نتائج الدراسة التطبيقية أن المهارات الإدارية للعاملين في مختلف أجهزة الدولة الإيلة تتفاوت حسب خصائص هؤلاء العاملين حيث ترتفع بين العاملين المقيمين في المناطق الإدانه الحضرية وحملة المؤهلات العليا وكبار السن وذوات المستوى الاقتصادي والاجتماعي مقاساً بنوع المسكن والحالة الاجتماعية.

r كما بينت قائمة الاستقصاء المتمع المدروس بشكل جيد وكاننت معظم إجابات عينة الدراسة موافق على جميع عبارات الإبداع وهو ما وضحه اختبار ويلكوكسن. 
r) كما أن أراء عينة الدراسة تثير إلى الموافقة على مهارات الأيدى العاملة وكذلك جميع العبارات التى تخص التتمية المستدامة.

ء) وقد أوضحت النتائج وجود علاقة إرتباط طردية (إيجابية) ذات دلالة احصائية بين

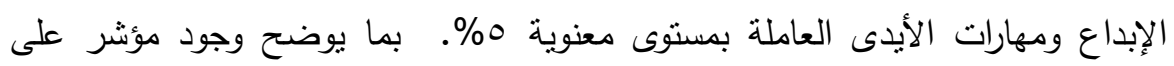
إمكانية ظهور نأثير للإبداع على مهارات الأيدى العاملة.

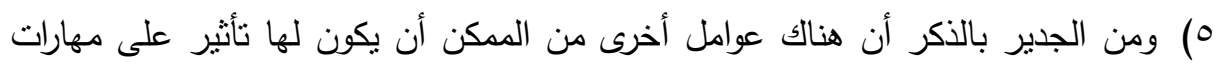
الأيدى العاملة لم بتم تتاولها بالدراسة الحالية.

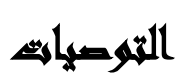

من واقع النتائج السابقة ولتحقيق أهداف الدراسة يستعرض الباحثون مجموعة من التوصيات التي بمكن أن نساعد في معرفة دور الإبداع في رفع مهارات الأيدي العاملة لتحقيق التتمية المستدامة. 1) هناك حاجة ماسة إلى تتظيم الدورات التدريبية وورشات العمل التدريبية وعقد المؤتمرات

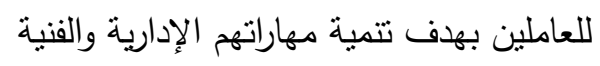

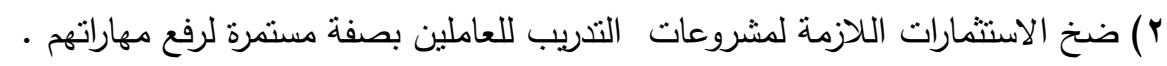

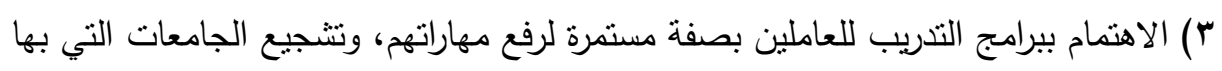
أقسام متخصصة على زيادة عدد الخريجين المتخصصين ورفع مستواهم العلمي . ؛) المساهمة في دعم عقد هذه الدورات والورشات والمؤتمرات باستمرار وبصفة دورية واعنبار ما ينفق على هذه الفاعليات والأنشطة استثمار وتتمية. 


\section{Intos}

استكمالًا للمسيرة العلمية اقترح الباحثون اجراء عدد من البحوث الهدف منها القاء

$$
\text { الضوء على دور الابداع في رفع مهارات الايدي العاملة ومن هذه المقترحات : }
$$

(1) يقترح الباحثنون اجراء دراسة تقيس دور التفكير الابتكاري على اداء العاملين بالمنظمات

بأنواعها.

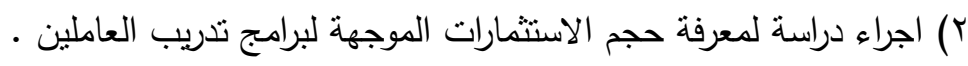

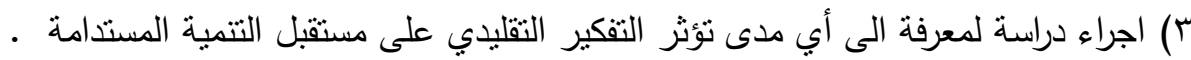

\section{المرالئe}

طه الروانثدة، أثز ممارسة الإدارة بالتجوال على السلوك الإبداعى فى شركة البوتاس العربية،

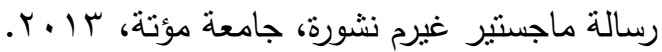

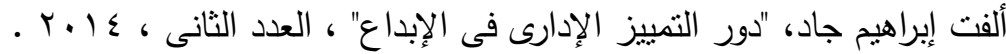

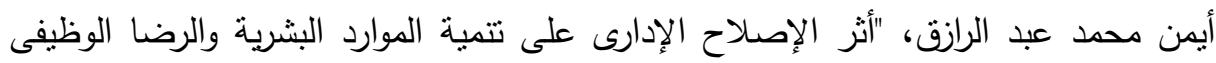

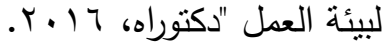

حسن أبشر الطيب (9191 )): التفكير الإبداعي، دمشق: دار الرضا للنشر •

حسن عبد الجواد" ، دور الثقافة البيئية فى تتمية اللوك الإبداعى لدى كثير من العاملين بالهيئة

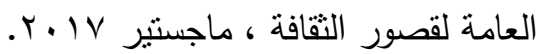

حسين محمد حسين، "أثر ثقافة المنظمة على نتمية القدرات الابتكارية للعاملين "العدد الأول، $.4 \cdot 11$

حمدى محمد نور ، "دور الإبتكار المفتوح فى تحسين عمليات نقل المعرفة، العدد الرابع،

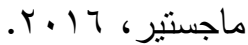

دالي صلاح الدين "إطار مقتر لقياس تأثثر الموارد البشرية على تحقيق الميزة التتافسية

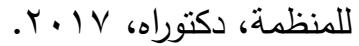

$$
\begin{aligned}
& \text { المجلد التاسع والأربعون، العدد العاشر ، جزء (V) نوفمبر .T.T }
\end{aligned}
$$

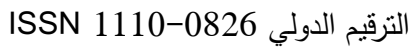




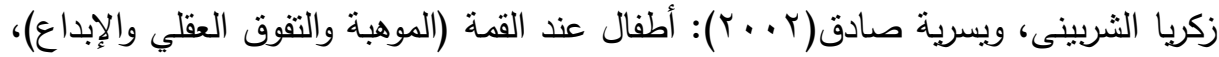

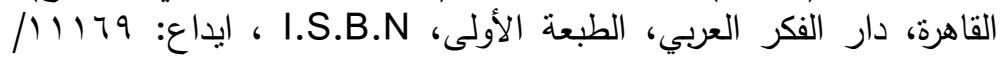
. r. . I

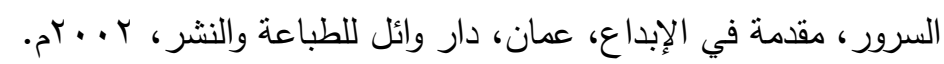

سليمان سالم الحجايا، ضغوط العمل وعلاقتها بالسلوك الإبداعى لدى مديرى المدارس الثانوية الثانية

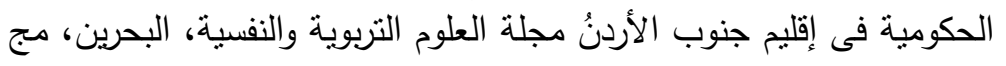

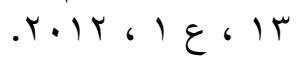

سمية حنفى حمدان، الأثر البيئى لاستخدام إدارة البداع والابتكار لتحقيق الأداء الحكومى الإهى

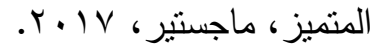

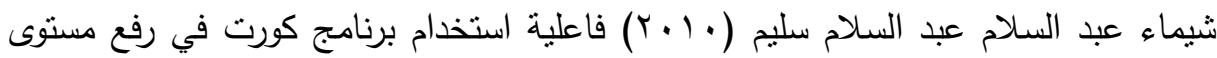

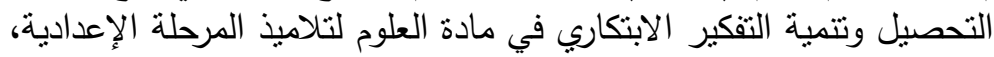

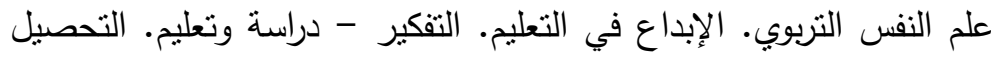

$$
\text { الدراسي. التفكير الابتكارى. }
$$

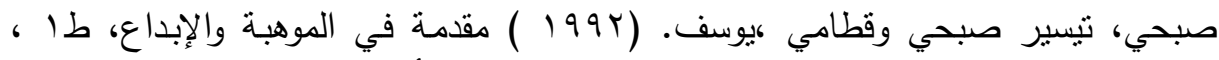
المؤسسة العربية للاراسات والنشر ، عمان: الأردن.

طارق رضوان محمد رضوان: "اثر خصائص منظمات التعلم فى السلوك الإبداعى للعاملين دراسة تطبيقية على البنوك التجارية المصرية" مجلة التجارة والتمويل (كلية التهات

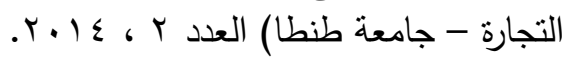

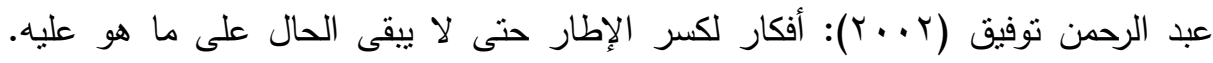

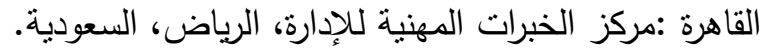

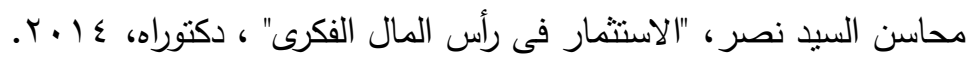

محمد سلامة، "الإدارة الخضراء للموارد البشرية ودورها فى تحسين أداء العاملين بالإدارات

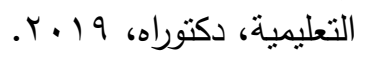

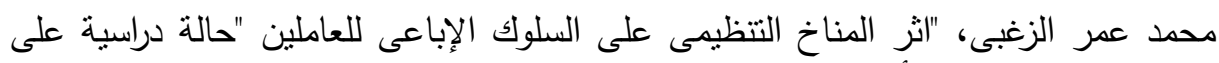

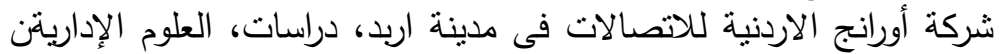

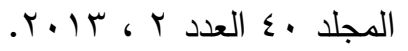

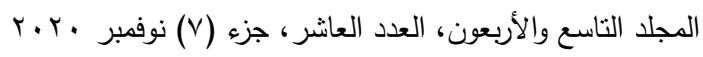

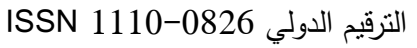




$$
\begin{aligned}
& \text { مجلة العلوم البيئية } \\
& \text { معهد الدراسات والبحوث البيئية - جامعة عين شمس لئة }
\end{aligned}
$$

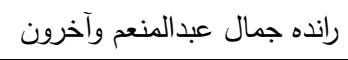

$$
\begin{aligned}
& \text { مصطفى سيوف: الأسس النفسية للإبداع الفنى - فى الثُعر خاصة دار المعارف بمصر } \\
& \text { القاهرة 1911. }
\end{aligned}
$$

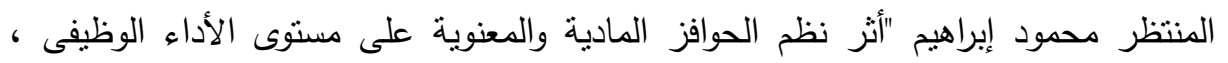

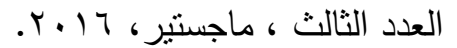

$$
\begin{aligned}
& \text { ناصر محمد سليمان " أثز إدراك العاملين للعدالة التتظيمية على السلوك الإبداعى" ، العدد } \\
& \text { الثالث، ماجستير ، ـ أ.ب. } \\
& \text { نجاة محمد عبد الوالى " التتمية المستدامة وأهيتها فى الطون العربى، العدد الثالث، مجلد الثيا } \\
& \text { r.Ir 6 } \\
& \text { نعيمة عمر محمد" أثز أبعاد القدرات الابتكارية على الأداء الإدارى، العدد الرابع، ماجسنير ، } \\
& \text { r. } 17
\end{aligned}
$$

Neha kumara, Nishat afroz, "the impact of organizational justice on organizational commitment and creative behavior among thermal power industrial employees", IOSR Journal of Humanities and Social Science (IOSR-JHSS) voume 16, Issue, 2013.

Solmaz Moghimi \& indra devi subramaniam, "Employees' creative Behavior: The role of Organizational Climate in Malaysian SMEs, Intermational Journal of Business and Management, Vol,8, No.,5, 2013.

Torrance, Runco, M. A., Millar, G., Acar, S., \& Cramond, B. (2010). Torrance tests of creative thinking as predictors of personal and public achievement: A fifty-year follow-up. Creativity Research Journal, 22(4), 361-368.

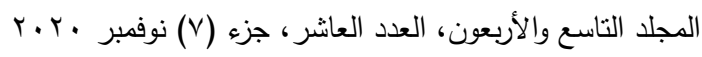

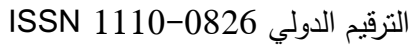




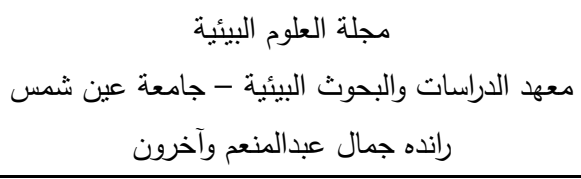

\title{
A PROPOSED FRAMEWORK FOR THE ROLE OF THE INNOVATION" IN RAISING THE SKILLS OF THE WORKERS TO ACHIEVE SUSTAINABLE DEVELOPMENT
}

\author{
Randa G. A. Mohamed ${ }^{(1)}$; Osaama Farid ${ }^{(2)}$ \\ and .Houda I. A. Hailal ${ }^{(3)}$
}

1) Post Grad., Student, Institute of Environmental Studies and Research, Ain Shams University 2) Faculty of Commerce, Ain Shams University 3) Institute of Environmental studies and research, Ain Shams University

\begin{abstract}
This study aimed to know the reality of creativity administrative and its relationship with the performance of managers in the Ministries of Gaza strip .

The study relied on descriptive approach, Questionnaire has designed as a means to collect the necessary data, it distributed to a sample study, were analyzed (305) Questionnaire as a rate (82\%) of the original of sample size by using the statistical program (spss) , hindicators supports the topic of the study .

The most important results of study:

1- The managers of the Ministries of Gaza Strip has all Distinctive capabilities for personal creative with a high degree .

2- Organizational variables under study contribute to varying degrees in the provision of Creative environment .The reality of creativity administrative in Gaza Strip ministries overall an Is acceptable .The process of performance appraisal of the Ministries of the Gaza Strip are not correctly and not effectively to serve the employee and the ministry together.

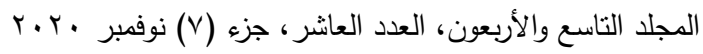

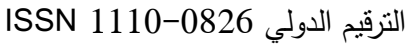




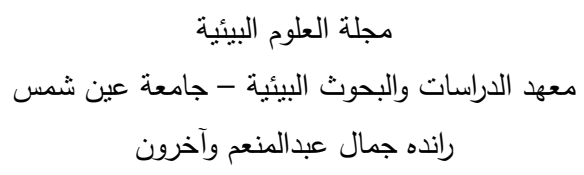

3- The reality performance of managers in the Ministries of the Gaza Strip .

Overall is an acceptable .

\section{The most important recommendations of study :}

1-Establishment of an incubator department for creativity or the establishment of the so-called (Ideas Bank).

2-Develop a strategy based on precise criteria for the detection of Creators and talented managers .

3-Work on decentralization and delegation of authority and the participation of subordinates in decision-making .

4-Activation of the incentives system on professional standards include excellence and creativity in performance and reward the creators .

5-Revision of performance appraisal system to include objective principles clear appraisal criteria, to ensure that the employee inform on the appraisal results.

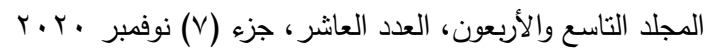

$$
\begin{aligned}
& \text { الترقيم الدولي 0826-1110 }
\end{aligned}
$$

